\title{
Linking Sustainability-Oriented Marketing to Social Media and Web Atmospheric Cues
}

\author{
Affan Ahmed Khan ${ }^{1}$, Ming Zheng Wang ${ }^{2}$, Sadaf Ehsan ${ }^{3, *}$, Mohammad Nurunnabi ${ }^{4,5, *(D)}$ and \\ Maaida Hussain Hashmi ${ }^{6}$ \\ 1 Institute of Systems Engineering, School of Management Science and Engineering, \\ Dalian University of Technology, Dalian 116024, China; affanzai@hotmail.com \\ 2 School of Management, Zheijiang University, Hangzhou 310058, China; wangmzh@zju.edu.cn \\ 3 Department of Management Sciences, COMSATS University Islamabad, Lahore Campus, \\ Punjab 54000, Pakistan \\ 4 Department of Accounting, Prince Sultan University, Riyadh 11586, Saudi Arabia \\ 5 St Antony's College, University of Oxford, Oxford OX2 6JF, UK \\ 6 Department of Economics, COMSATS University Islamabad, Lahore Campus, Punjab 54000, Pakistan; \\ maaidahashmi@cuilahore.edu.pk \\ * Correspondence: sadafehsan@cuilahore.edu.pk (S.E.); mohammad.nurunnabi@sant.ox.ac.uk or \\ mnurunnabi@psu.edu.sa (M.N.)
}

Received: 17 April 2019; Accepted: 6 May 2019; Published: 9 May 2019

\begin{abstract}
Acknowledging the widespread use of social media and the exponential growth of digital technology, a number of reputable organizations and small and medium-sized enterprises (SMEs) have shifted their traditional marketing tools to approach new markets for the growth of their businesses. Such companies have introduced their business over social media in order to gain greater attention from the consumers. However, the major concern addressed regarding how products and services are promoted online is regarding sustainable marketing. It is explored that most of the consumers tend to view online businesses by visualizing essential factors that reflect sustainability and thus, SMEs have started to analyze specific web atmospheric cues, which contribute in developing social media according to consumer behavior and their perceptions. To assess the research area, the following study is performed to understand possible measures that are significant in bridging business and consumer needs. This research incorporates a quantitative research method for gathering specific data by using questionnaires. From the findings of the research, it is analyzed that consumers are likely to perceive and give attention to social media by analyzing specific cues, including visuals, ethics, information, social, and security. It is concluded that SMEs could foster their online businesses by adopting effective sustainable marketing strategies aligned according to specific web atmospheric cues.
\end{abstract}

Keywords: social media; SMEs; sustainability; web atmospheric cues; consumers; online business; sustainable marketing strategies; consumer behavior

\section{Introduction}

Since the evolution of digital technology, a number of reputable organizations, as well as SMEs, have shifted their traditional marketing tools so that it would become easy to approach a competitive market for the growth of its business. However, such companies strived to adopt necessary changes, but it required different business strategies that are quite challenging in terms of minimizing exceptions among traditional and modern developments [1]. With the revolution in increasing digital growth of the businesses, the rise of social media is evident in recent years, which is considered to be a phenomenal development in the era of technology. Perhaps, the increasing trend of social media 
has affected business dynamics in multiple ways due to which both its virtues and shortcomings are evident in the light of online businesses [2].

Most SMEs strive to overcome their business challenges by adopting social media services for understanding preferences and likeness of customers regarding their business facilities [3]. Despite transformational changes in the business environment, a major goal for performing significant measures in digital tactics is that customers are likely to communicate their preferences without any barriers. Thus, the practice of using social media as a significant platform in a business environment is becoming increasingly successful, which has introduced more opportunities to expand services across the border level [4]. A number of researchers have investigated digital transformation in SMEs, which highlighted ease of use, preferred medium, and smooth communication based on the number of users and their satisfaction from the use of social media. Researchers suggested that utilization of social media joined with certain organizational and environmental form configurations drive firms to high innovation performance and is further explored that use of social media platforms is very high in SMEs [5].

In 2017, the growth of the use of social media increased and vastly expanded. While a number of social platforms have emerged in recent years, it has benefitted organizations in terms of creating brand awareness, engagement, revenue, as well as an exponential increase in sales. These platforms are mainly used for establishing business and promoting services. From a number of scientific reports, it is analyzed that the most demanding and frequently used social media platforms are Facebook, Twitter, Instagram, YouTube, and LinkedIn (Appendix A Table A1) [6]. These platforms have facilitated businesses in achieving goals by creating effective business-to-business (B2B) objectives, as well as results leading to maximum profitability of the organizations. Based on recent statistics, the highest number of users is reported to be using Facebook (89\%) followed by LinkedIn (83\%), YouTube (81\%), Twitter (80\%) and Instagram (56\%) [7].

SMEs understand the significance of sustainability practices and it demands for several improvements to corporate social responsibility and marketing efforts [8]. Using the statistics, SMEs have analyzed the main reasons for the growing interest of users in such platforms and thus, a number of businesses have gained digital placement in recent years [9]. For this purpose, many researchers have also participated in conducting researches to investigate how SMEs are integrating their strategies to attract customers from all over the world in terms of increasing their revenues and creating brand awareness at the same time [10]. Hence, the trending subject is becoming a vital scope of study as it is providing more guidelines for the companies to extend their services for achieving competitive advantage. Despite traditional measures enforced in promoting the businesses, social media also provides opportunities to companies for using sustainable marketing strategies, which have guaranteed numerous advantages in the current date.

Although many consumers have opted for social media while engaging social activities and entertainment, it is also been used for utilitarian purposes. Due to changing trends in perspectives, most consumers tend to utilize these platforms for purchasing online products [11]. Through such initiatives, most SMEs have grown their businesses by attracting consumers using innovative tools and technologies. However, such measures have also influenced the mindset of the consumers as they are likely to approach these platforms, which in turn are designed to deliver user needs to the greatest extent. Thus, the following research investigates the impact of sustainable marketing strategies as well as the major elements that are considered vital in terms of gaining greater user attention.

Since social media is increasingly being used in most industries, it is illustrated by the researches that SMEs measure these trends by exploring the extent of cues that are influencing the consumers in a greater way. It is analyzed that in order to increase the purchasing power of the consumers, SMEs have to understand dynamic and appealing elements that engages consumers in the actions and events updated on their social media accounts [12]. However, the concern have become one of the most important facts that have widely changed the overall design measures of SMEs. 


\subsection{Research Gap}

There are still some unexplored factors in a number of past studies due to lack of availability of information, as well as limited access to population data that could be a valuable contribution with the scope of this research. However, some of the revised literature addressed the concept of sustainable marketing, but due to initial limitations in analyzing its impact on the consumer mindset, it has provided little evidence for a major shift from consumers to digital media [6]. Thus, these gaps are taken into consideration in order to investigate the potentials of social media and its connections with sustainability in order for SMEs to attract consumers and achieve more outstanding business goals. Moreover, the research also tends to explore the extent of benefits caused by understanding the needs of sustainable social media marketing for establishing a productive relationship between the SMEs with a compelling online presence and their consumers [2]. It is widely known that today's consumers have more interest in seeking leisure and entertainment on social media, which drives their purchasing power and thus, SMEs tend to increase their customer retention rate. This phenomenon is also explained in the research because only limited evidence was explored in the past $[9,12]$.

\subsection{Rationale for Research}

As social media is an effective method to bridge business and consumer needs, there is a need to understand the aspects that could make the relationship between SMEs and consumers stronger. On the other hand, it is important to introduce the concept of sustainable marketing, which is a growing trend in the market for achieving digital promotion objectives through including such attributes [13]. Furthermore, the purpose of performing the research is to explore the behavior of consumers with respect to adopting sustainable social media marketing strategies in purchasing products online from SMEs. Different cultures will be studied in order to assess the extent of sustainable marketing strategies acceptance so as to create a platform that maximizes profitability and growth for SMEs in such a competitive industry.

\subsection{Research Objectives}

The following study is based on the objectives which are to:

1. Investigate the core aspects of sustainable social media marketing and its impact on consumer behavior

2. Understand the need to influence consumers through the adoption of modern strategies and technologies to promote SME business online

3. Analyze the importance of web atmospheric cues that are subjected in sustainable social media marketing for establishing online SMEs business

4. Evaluate the impact of sustainability and consumer needs in accomplishing business objectives effectively

5. Recommend strategies to improve online marketing for future productivity of SMEs

\subsection{Research Questions}

1. What are the major aspects of sustainable social media marketing and how these factors are important in influencing consumer behavior?

2. How are SMEs promoting their online businesses by adopting modern strategies and technologies in placing their online presence effectively?

3. Why are web atmospheric cues vital in defining sustainable social marketing strategies as a productive measure in establishing SMEs business online?

4. To what extent does sustainable marketing on social media impact consumer needs?

5. How are sustainable marketing strategies benefiting SMEs in accomplishing their business goals? 


\section{Literature Review}

\subsection{Social Media}

Srinivasan et al. [10] investigated the definition of social media as an innovation in the second generation of web development and design, which emerged to provide immense facilitation to users in terms of communication, security, sharing of information, interoperability, and online collaboration. The emergence of social media is addressed as a strategy to overcome numerous challenges faced by the users regarding different social activities which were limited due to various legal and ethical restrictions [13]. The paper employs the concept in advocating its major use in most recent businesses gaining profitability since past few years. It is also investigated that most of the companies have shown their concerns and acceptability of platforms had influenced consumer behavior at large [14]. A study also found that, competition is a critical driver in the choice of firms to embrace social media tools for innovation and development purposes. At the point when firms sense that competitive pressure is rising, they attempt activities so as to tempt consumers and reposition themselves in the market [5]. Literature also reveals that the majority of SMEs have adopted social media in their business promotion and thus, it has created brand awareness and brand trust to the greatest extent [15].

In the study of Siricharoen [16], it is identified that social media is becoming one of the essential tools in business that has not only influenced the environment but also impacted consumer behavior at large. While using social media applications, users get opportunity to build their interpersonal skills and effectively collaborate with business matters so that productive results could be achieved [11]. The study analyzed major causes of shifting business services to online channels and thus, it was explored that organizations tend to manage budgeting and finance for which social media is one of the significant sources that increasing productivity to the greatest extent [2]. Based on the results of the research, it is found that social media is significant in promoting the business so that huge number of consumers could be attracted for increasing their revenues.

The study proposed by Yan and Carol [17] also investigated the role of social media in SMEs. According to study, social media has influenced SMEs to the greatest extent as they are benefitted in terms of using strategies for approaching target consumers [18]. Due to massive integration of social media in current SMEs, business promotion and brand awareness have increased due to which a potential growth in business performance is also witnessed [19]. The utilization of social media helps organizations to implement for open innovation across all innovation funnels and it intensifies the need of technological and organizational alignment from front-end ideation stages towards commercialization when social media is embedded into the system [20]. The purpose of the research was to explore significant aspects of social media that are incorporated by SMEs in order to gain effective productivity in such competition. From the results of the research, it is analyzed that numerous aspects of social media are determined in order to flourish the business using online channel. Some of the aspects explored are governance, accessibility, monitoring and managing, and timely feedback [21].

\subsection{Social Media Determinants}

Social media is a vital technology that became popular within the industry due to its diverse determinants that are subjected to bring positive change in business performance. Different studies have explored different determinants of social media with which organizations are expanding their boundaries to offer products and services using online media. In recent years, many SMEs have established their online existence by utilizing the facilities that are important for establishing a productive brand concept among the consumers [22]. Hence, different determinants are mainly analyzed to ensure that social media is an effective tool that offers numerous advantages in terms of promoting businesses. 


\subsubsection{Participation and Engagement}

According to McCay-Peet and Anabel Quan-Haase [23], participation and engagement of users are the important factor in analyzing the effectiveness of a social media platform. It is estimated that engaging content and elements on the social media are significant in terms of increasing the size of the audience [15]. The main purpose of introducing such measures on social media platforms is to encourage feedback and user involvement, which further increases the number of targeted audience and profitability of the company [14,24]. Thus, using approaches for participation and engagements also minimizes challenges between SMEs and consumers [25].

\subsubsection{Conversation}

Effectiveness of social media is also measured in terms of communication, which is often explored in a two-way mechanism [18]. According to Wirtz et al. [26], social media facilitate its users in terms of providing ease of communication. SMEs tend to use features of social media so that it would make users enable to communicate and share their opinions with the organization. It is often used as an opportunity as it provide options to users for letting them communicate with the representatives of the business so that their queries could be resolved effectively [27].

\subsubsection{Community}

Using social media, users are often involved in establishing digital community where a number of different users collaborate on the basis of different attributes. According to Martins [28], social media provide opportunities to users in terms of communicating with other users who belong to different cultures and backgrounds [9]. In this way, online communities are formed where people with different skills, interests, likeness, political associations, and educational backgrounds are involved and thus, discussions are done on various subjects and domains [27]. Through such facility, most of the users have also linked them socially due to which social relationship barriers are reduced to the greatest extent. Furthermore, SMEs also use such features with respect to targeting an audience in accordance with their contributions, interests, and competition to achieve different yet more [12]. In addition, social communities have also enabled SMEs to understand consumer behaviors and their preferences in regards with the launch of new products and services [25].

\subsubsection{Usability}

With respect to usability of social media, it becomes complex and challenging for users who have no past experience in using digital technology [29]. According to Jamalzadeh [30], usability is a critical factor in terms of providing effective human interaction benefits as it guarantees that the design of such user interfaces are relatively easier to use [15]. Thus, usability plays a vital role in increasing the number of users on specific application. In this regard, SMEs also understands the significance of usability therefore, some online brands and businesses uses limited options and clean designs in order to attract customers for a longer period of time.

\subsubsection{Transparency}

Based on the study of Martins [28], transparency refers to the extent of information provided by organizations that is visible and clear to its customers. Mainly, transparency is identified on the basis of critical information available for the access of users. In the current digital presence, most of the people tend to opt for online platforms, applications, and websites which states clear and precise information that is relevant for building trust regarding the organization $[14,18]$. Thus, SMEs also take this factor into consideration so the relationship with consumers could be maintained while their satisfaction could be achieved [29]. 


\subsubsection{Sustainability and Marketing}

In the last decade, social media and sustainability have played an increasingly important role in improving businesses management and exchange. Together, they contributed to driving the companies at the peak of transparency, opening up opportunities for increased commitment, forcing organizations to reposition their role in society and aligning individuals, firms and communities towards common goals [31]. Sustainability has become the part of many disciplines and hence, the marketing is not beyond exception. In general, sustainability marketing involves the establishment and maintenance of sustainable customer relations [32]. The process of transition to sustainability marketing encompasses the combination of social and environmental into conventional marketing and thinking [33]. However, sustainability marketing is incalculably understudied [34].

Based on the current trends of digital existence and online resources, most of the SMEs are looking for ways in which they tend to encompass sustainability of social media. In this regard, interactive marketing and promotional measures are performed so that organizational and consumer relationship could be strengthened. In the study of Kang and Byungho Park [35], it is discussed that new trends have evolved in the area of social media which indicates the need of using useful and interactive strategies for achieving consumer attention. Thus, the concept of real-time marketing is initiated in this regard, which influences organizations to adopt measures that are not only easily implemented but also attract consumers in a most appropriate way [11].

In online media, the word "sustainability" is used in terms of using tactics that guarantees environment-friendly outcomes as well as limits the challenges associated with the organizational and consumer growth. In the paper of Minton et al. [1], green marketing is critically evaluated to ensure the need of using the steps that are important in determining the potentials of consumers as well as the profitability of the organizations. From the research, it is also identified that consumers give their positive response in terms of sustainable marketing as they appreciate organic strategies, products, and services rather than artificial and complex services. In contrary to the evidence regarding green marketing, it is also studied that consumers often provide their complex responses. For this reason, many SMEs and other organizations are still looking for ways that would be sustainable as well as productive in terms of achieving consumer attention [36].

\subsection{Web Atmospheric Cues}

Dailey has defined web atmospheric cues as mindful design of web environment to create positive effects on users (e.g., positive cognitions, positive psychological contracts, consumer word-to-mouth communication, etc.) to increase the favorable consumers' responses (e.g., revisiting sites, browsing, etc.). Few researcher observed the substantial influence of these necessary cues on consumers' emotions (stimulation and joy) and it is impulsive and subliminal [37,38]. When marketer designs web interfaces by incorporating different colors, sounds, layouts, and navigation instructions, they are employing web atmospherics cues [39].

\subsubsection{Visual Cues}

In the social media, one of the important atmospheric cues identified with respect to consumer behavior and their perception is the visual attributes, which plays significant role in attracting the users. Based on visual attributes, social media is often analyzed on the basis of its layouts, designs, colors, text, content, and other major visual features [40]. With respect to social media and related applications, visual cues are significant in terms of comprehensive aesthetic quality, including design, images, display, and ease of using the interface [41]. All of these visual cues are highly considered in most of the social media platforms while SMEs also take significant steps in this regard to best retain consumers [15]. Furthermore, it is perceived that due to using important visual-based measures in designing social media, SMEs are likely to gain huge consumer attention as they tend to generate 
pleasure emotional responses. A study suggests that paying more attention to web visual design will generate an encouraging response and grabs consumer attention [42].

\subsubsection{Information Cues}

Some studies focused on considering and evaluating the features of web portal like its informativeness and usefulness, defined as "informativeness; the capability of portal to make information available to the shoppers" [43] also a report defined the components of layouts and outer appearance as exciting, enjoyable, peaceful and highly imaginative entertainment [44]. When users log in to social media platform, they tend to look for interesting content and information regarding the offers and services [19]. Moreover, SMEs use the cues to make sure that consumers are provided with relevant information about their products so that their satisfaction could be achieved [36]. Some of the important information cues in social media are identified as qualitative details regarding the product and its relevance with respect to consumer preference [45].

\subsubsection{Ethics Cues}

Most of the SMEs on social media tend to retrieve specific information from the users in order to maintain their record for future marketing and promotional operations [24]. However, consumers are reluctant to share their information on online platforms due to security concerns [40]. Moreover, SMEs provide such ethical consents to the consumers so they can share their information without any hesitation and thus, it is considered as another most important atmospheric cue due to its sensitivity and consumers' concerns [46]. In addition, consumers are concerned about their information being shared with third-party without their permission which SMEs likely to consider while designing their social media existence [47].

\subsubsection{Social Cues}

In the light of atmospheric cues, social cues have been associated with social media to the greatest extent. With respect to social interaction on social media platforms, consumers provide emotional response when they explore relativity and environment-based features on the applications [45]. Moreover, it becomes easy for the consumers to use social media when the organization has used easy and flexible options for interacting with the representatives [41] and thus, it becomes effective to receive fruitful response from the consumers.

\subsubsection{Security Cues}

Based on the productivity of social media and its effectiveness as well, security is one of the concerns that consumers tend to experience while using the digital features [12]. Almost all of the consumers are reluctant to share their information on social media platforms due to insensitive approaches implemented for securing critical data [48]. However, SMEs take this point into consideration as it they tend to involve consumers in their profitable growth and therefore, they take care of the important information from being used illegally. In this regard, consumers' emotions and their behavior is analyzed at large [49].

\subsection{Hypotheses}

The following hypotheses are derived on the basis of above discussion.

Hypothesis 1 (H1). Visual cues in sustainable marketing on social media positively affect consumer behavior.

Hypothesis 2 (H2). Information cues in sustainable marketing on social media influences consumer behavior at large.

Hypothesis 3 (H3). Ethics cues in sustainable marketing on social media positively affect consumer behavior. 
Hypothesis 4 (H4). Social cues in sustainable marketing on social media effectively promotes products and services for developing positive consumer perceptions.

Hypothesis 5 (H5). Security cues in sustainable marketing on social media build strong relationships between SMEs and consumers.

\subsection{Theoretical Framework}

Figure 1 refers to the construct of this study.

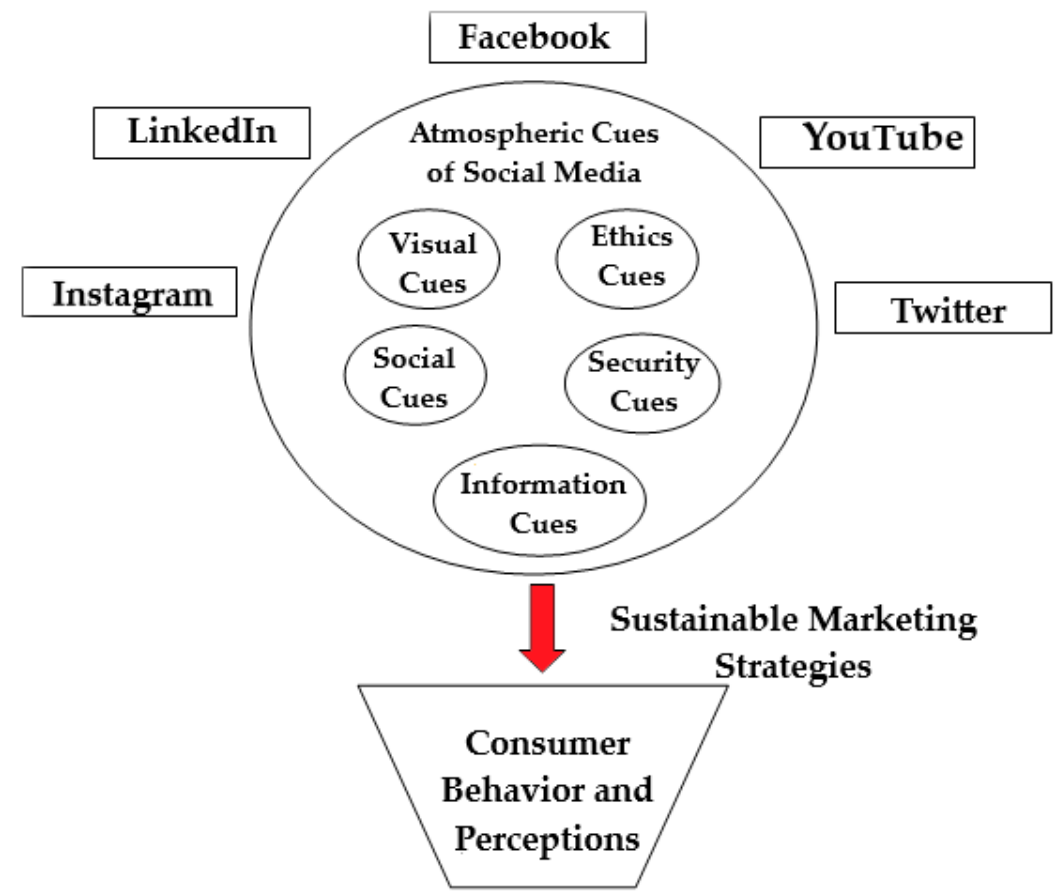

Figure 1. Theoretical framework.

\section{Materials and Methods}

\subsection{Research Technique}

A quantitative method is used to find the type of sustainability categories and ways to have consumers address such issues of marketing by utilizing social media platforms in terms of sustainability. The qualitative research is conducted through the use of peer journals involving encompassing of sustainability and social media coverage for the sustainability marketing content, involving the consumers and market trends itself. Furthermore, both research methods are used to investigate the extent of sustainability as its image is communicated by the consumers. In addition to this, the social trends are analyzed by using data collected from the consumers relating to the consumer preferences [36]. Additionally, as described previously, new terms and concepts are also researched upon and are evaluated throughout the research to elevate the significance of the topic. The quantitative research method includes questionnaire that is assessed and generated and concluded from the significant factors described above. The selected audience for the questionnaire is taken from a sample population that uses social media widely for different purposes, merely for the purpose of addressing the issues regarding sustainability in the social media posts. For the sustainability image criteria, we have focused on brands. Furthermore, the research also uses peer research construction method considering the cross cultural as well as business-related perspectives through latest social media trends and technologies, 
since, for the assessment of cross-cultural communication, it is vital to consider cultural differences among countries [50].

\subsection{Cross-Analysis}

The study follows the cross-analytical method of time horizon. Cross-analysis is a research method that indirectly helps to compare the common characteristics and differences of events, actions, and processes as units of analysis in different studies. Participation in the cross-analysis extends the competition of the competitor in only one case [51]. It stimulates the imagination of researchers, raises new questions, opens new dimensions, and creates alternatives, models, ideals and utopias.

\subsection{Sampling Unit}

Since the study aims to engage in discourse over the sustainability-oriented marketing to social media and web atmospheric cues, the sample population from which the data has been collected are mostly people who, comparatively, are more interactive with social media platforms, such as Facebook, Instagram, LinkedIn, YouTube and Twitter. This involves entrepreneurs, social media activists, students that are involved in e-learning, consumers of e-commerce websites, bloggers, and other professionals on social media sites. For the consideration of ethics and privacy of the sample, no specific names or organization has been mentioned in the study. The sample is, however, distinguished on the basis of the age group and other categories. This sample size involve majority of population between the age group of 20 to 40 years.

\subsection{Sampling Frame}

\subsubsection{Data Collection}

The sampling frame used for the conduction of the survey and polling is done through the Google Forms since it is the most convenient platform around the globe and the study itself involved the social media trends and consumers opinions. Our target population consisted of over 400 people using social media platforms. The final number of valid responses was 150, yielding a response rate of approximately $36 \%$, which was achieved after reminders to the respondents in order to reduce non-response bias.

\subsubsection{Data Analysis}

As for the evaluation of data gathered from the questionnaire, the data is imported and utilized on the SPSS software by IBM, through which it was expedient to generate the demographics. The mean of the data, standard deviation, and the correlation table are generated using the same software.

\subsection{Sampling Strategy}

The sampling strategies used for the convenience of the research survey are a combination of random sampling method as well as rational sub-grouping sampling method. The random sampling method employs the population belonging to diverse groups. The random method is used in the research because it tends to protect the evaluation from unseen aspects like unequal opportunities for groups to express their views and experiences [50]. On the contrary, rational sub-grouping method sounds entirely opposite, although it can be fairly utilized with the random sampling method. In the rational grouping method, the sample population is divided into meaningful groups. It helps in the understanding of the essential sources for variation. The groups are provided with similar environment and conditions. The rational sub-grouping method is utilized for suitability of sub grouping technique. Moreover, the technique is helpful in improvising, appraising, and tracking newest trends and developments against the ones usually followed. 


\subsubsection{Quantitative}

The quantitative data analysis is carried out with the help of generally used software to generate tables, graphs, charts and other statistical and non-textual representations [52]. This assists the readers in the understanding of the complex data. The raw data is not understandable these representations provide descriptions of the generated results. However, it depends on how well the researchers has identified and analyzed the data, the findings that were to be presented in a sequential or a logical order or the key findings itself. These are helpful in the discussion and result section.

\subsubsection{Qualitative}

Qualitative research is used to understand the underlying causes, opinions, and motivations. It provides information about the problem or helps providing ideas or suggestions for possible quantitative research. Qualitative research is also used to identify trends in ideas and perspectives, also to explore problems. The methods of qualitative data collection differ a lot in unstructured or semi-structured methods. Some common methods include focus groups (group discussions), personal interviews and participation/observation. The sample size is usually small, and the respondent is selected to meet this criterion.

\subsubsection{Likert Scale}

This is the most widespread resizing method in research studies, so this term is often used interchangeably with rating scales. In response to the Likert project, respondents indicated the degree of their agreement or disagreement in a series of symmetrical agreements allegations of disagreements. Therefore, this range reflects the perceived intensity of the subject. The Likert scale used in the sampling of data is a five-point Likert scale corresponding to each question: strongly agree, agree, neutral, disagree and strongly disagree.

\subsection{Research Measures}

There are certain ethical considerations to be taken care of while carrying out this research.

\subsubsection{Informed Consent}

Consent refers to the agreement with sample and their permission to carry out certain research using their experiences and knowledge. The sampling was done with consent of the respondents.

\subsubsection{Respect for Anonymity and Confidentiality}

When it comes to anonymity and confidentiality, no names of institutes, businesses, students, business people, or other professionals involved in the research are used or disclosed in the paper. However, freedom of choice was given to either mention the name of institute/organization/individuals on the questionnaire or not.

\subsubsection{Respect for Privacy}

The privacy of content, names, valuable information etc., was maintained throughout the research and in the paper.

\subsubsection{The Nature of the Research}

The research is for academic purpose only. 


\section{Results}

\subsection{Descriptives}

The sample size taken for research involved 150 people $(\mathrm{N}=150)$. The average age group range of the sample population ranges from 20 to 45.82; out of 150, sample size, 82 were females and 68 were males. Most people have completed their bachelors' degrees, some have completed masters' degrees, while a few people hold PhD qualifications.

Figure 2 represents the ratio of genders of sample population.

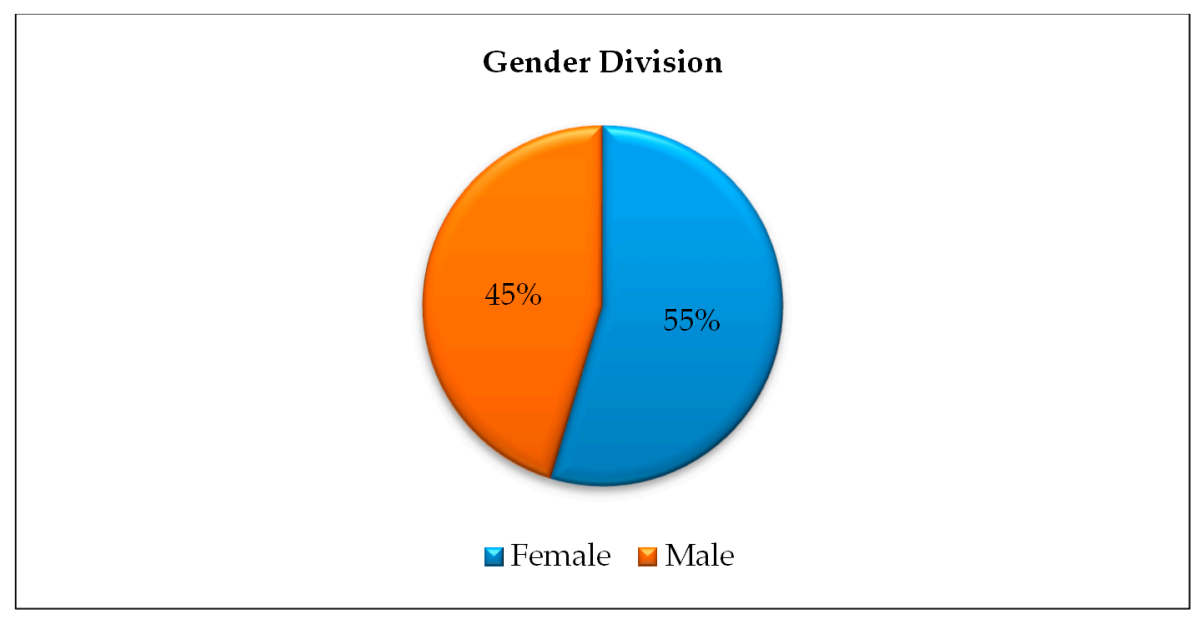

Figure 2. Gender division.

Figure 3 represents the division of age groups. The majority of people are aged from 31 to 35.

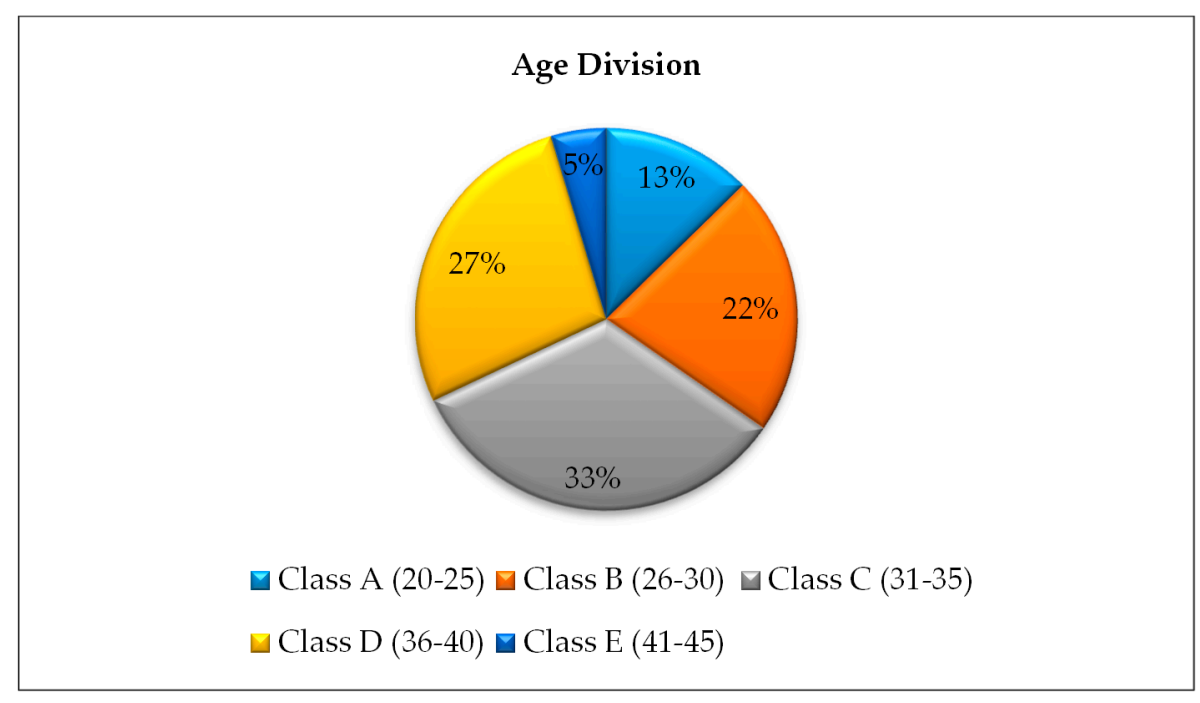

Figure 3. Age division.

Figure 4 represents division on population on the basis of qualifications. 


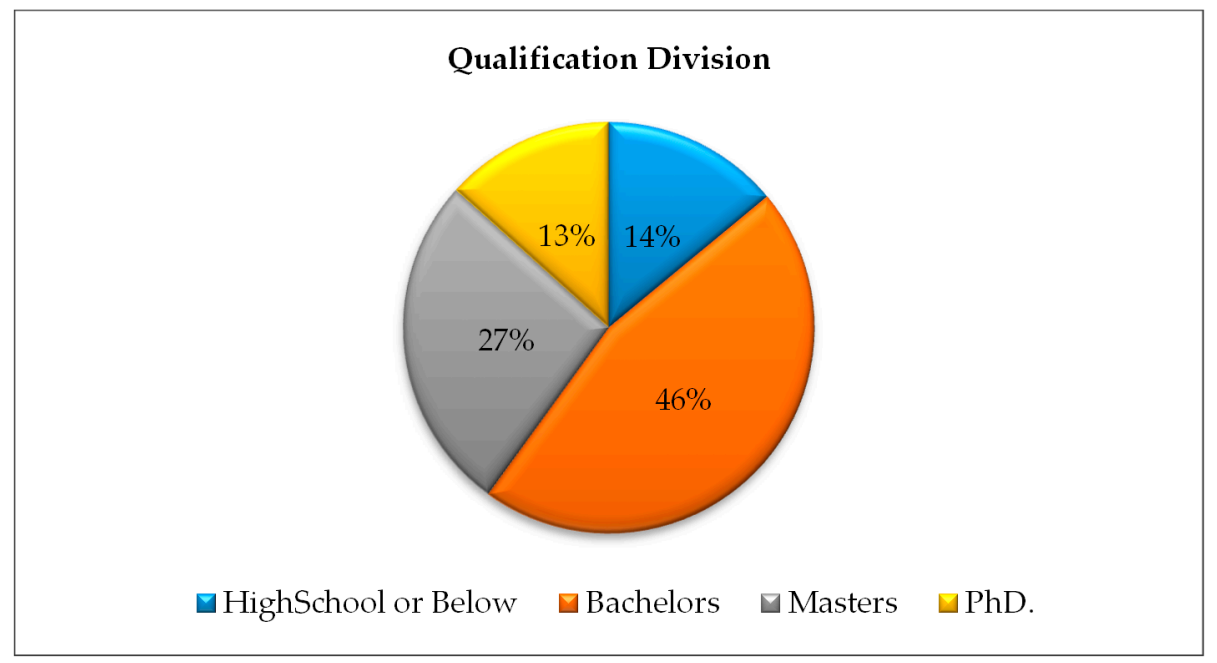

Figure 4. Qualification division.

Figure 4 represents the division on qualifications of respondents. Most of the people have acquired a bachelor's degree.

\subsection{Most Important Aspect of Sustainable Marketing Strategy}

In the Table 1, mean represents the majority of answers in an average value that lies between the possible answers on the Likert scale i.e., from 1 to 5 . Meanwhile, the standard deviation value indicates the quantity of answers that varied from the mean value. From the results of mean and standard deviation as shown in the above table, it can be seen that most of the people believed that visuals and ethics are the most important factors of social media pages or web applications.

Table 1. Mean and standard deviation of dependent and independent variables.

\begin{tabular}{|c|c|c|c|c|}
\hline S. No. & Questions & Variable & Mean & $\begin{array}{l}\text { Standard } \\
\text { Deviation }\end{array}$ \\
\hline 1. & $\begin{array}{l}\text { Which of the following aspect of sustainable marketing } \\
\text { strategy impacts consumer behavior? }\end{array}$ & $\begin{array}{c}\text { Dependent } \\
\text { Variable-Sustainability }\end{array}$ & 2.906667 & 1.332841 \\
\hline 2. & $\begin{array}{l}\text { An attractive layout of social media influences consumers to } \\
\text { approach business }\end{array}$ & Visuals-V-01 & 1.88 & 0.975677 \\
\hline 3. & $\begin{array}{l}\text { Use of engaging colors and graphics adds visual impression } \\
\text { on consumers }\end{array}$ & Visuals-V-02 & 1.68 & 0.805351 \\
\hline 4. & SMEs use pleasing designs for promoting their products & Visuals V-03 & 3.8 & 1.061846 \\
\hline 5. & $\begin{array}{l}\text { Use of attractive images and limited content positively } \\
\text { impacts consumer perceptions }\end{array}$ & Visuals V-04 & 1.826667 & 0.895527 \\
\hline 6. & $\begin{array}{l}\text { Up-to-date information increases chances of more } \\
\text { consumer attention }\end{array}$ & Information I-01 & 2.153333 & 1.2464 \\
\hline 7. & $\begin{array}{l}\text { SMEs uses accurate information for their targeted } \\
\text { consumers to promote their products online }\end{array}$ & Information I-02 & 3.586667 & 0.97751 \\
\hline 8. & $\begin{array}{l}\text { Information on social media is quite helpful for letting } \\
\text { consumers to take positive decisions }\end{array}$ & Information I-03 & 4.026667 & 0.881934 \\
\hline 9. & $\begin{array}{l}\text { Consumer behavior depends on the nature of information } \\
\text { provided by SMEs on social media websites and pages }\end{array}$ & Information I-04 & 1.62 & 0.641621 \\
\hline 10. & $\begin{array}{l}\text { Sharing consumer reviews and their pictures on social } \\
\text { media is ethically acceptable to attract other consumers }\end{array}$ & Ethics E-01 & 3.186667 & 1.327998 \\
\hline
\end{tabular}


Table 1. Cont.

\begin{tabular}{|c|c|c|c|c|}
\hline S. No. & Questions & Variable & Mean & $\begin{array}{l}\text { Standard } \\
\text { Deviation }\end{array}$ \\
\hline 11. & $\begin{array}{l}\text { Using information from other sources without giving credits } \\
\text { affect consumer perceptions }\end{array}$ & Ethics E-02 & 4.133333 & 0.938846 \\
\hline 12. & $\begin{array}{l}\text { SMEs asking for personal information for their } \\
\text { organizational operations are ethically inappropriate and } \\
\text { affects consumers a lot }\end{array}$ & Ethics E-03 & 3 & 1.099115 \\
\hline 13. & $\begin{array}{l}\text { SMEs open for reviews on social media positively affects } \\
\text { consumer behavior }\end{array}$ & Societal S-01 & 1.633333 & 0.649384 \\
\hline 14. & $\begin{array}{l}\text { Active customer support and responses to queries enable } \\
\text { consumers to give more attention to the business }\end{array}$ & Societal S-02 & 1.633333 & 0.659639 \\
\hline 15. & $\begin{array}{l}\text { SMEs launching giveaways and events to promote their } \\
\text { products highly affect consumer perceptions }\end{array}$ & Societal S-03 & 1.793333 & 0.861532 \\
\hline 16. & $\begin{array}{l}\text { SMEs fulfilling consumer needs by posting offers on social } \\
\text { media attract consumers a lot }\end{array}$ & Societal S-04 & 2.04 & 0.873779 \\
\hline 17. & $\begin{array}{l}\text { SMEs limited to few delivery options on social media are } \\
\text { likely to lose consumers }\end{array}$ & Societal S-05 & 1.94 & 0.899142 \\
\hline 18. & $\begin{array}{l}\text { Sharing security and privacy policy strengthens } \\
\text { organization-consumer relationship }\end{array}$ & Security C-01 & 1.686667 & 0.752059 \\
\hline 19. & $\begin{array}{l}\text { SMEs restricting sharing personal information to third party } \\
\text { positively influences consumer behavior }\end{array}$ & Security C-02 & 1.813333 & 0.745336 \\
\hline 20. & $\begin{array}{l}\text { SMEs promoting their products using variety of payment } \\
\text { options are likely to gain more consumer attention }\end{array}$ & Security C-03 & 1.886667 & 0.839756 \\
\hline
\end{tabular}

\subsection{Visuals}

As for the attraction of consumers, most of the people perceive that the layout of the social media or website plays an important role. The mean 1.62 and standard deviation 0.641 clearly indicates that the site must be neat and have a navigation system that is easy-to-follow so that it facilitates user to an accessible social media design. An easy-to-use design allows site visitors to access valuable and significant information. In addition, the matter on the site should not be problematic to operate and find. This involves the usage of engaging colors and graphics, as expressed in the third question where the mean is calculated as 1.68 and standard deviation as 0.805351 indicates that consumers assesses the look and feel of the social media page before making purchases. This ensures the fact that consumers also demands for an overall interactive design of the web page, however, according to the audience rating it is not something in application of the SMEs today. Furthermore, use of attractive images and limited content positively impacts users as observed from the ratings. However, few people believed that brand itself is not perceived from its name or logo but its appearance, layout, feel, and designs with respect to social media and user interaction.

\subsection{Information}

Most respondents believed the information offered by brands about their business and their products plays a significant role in creating new customers and that it should be up to date and revised regularly. The mean was shown to be 2.153 with a standard deviation of 1.2464. SMEs offer information today through their social media pages against the products offered by these brands to the consumer. A wide amount of data of ratings indicate that SMEs do not provide quality products or services as described on their e-commerce pages. The following question can be relatable with the information that is provided by SMEs today. With a mean of 4.026667 , it can be assessed that due to the presentation of fake information about businesses online, is not reliable to trust this information and it does not let consumers take positive actions. Thus, SMEs are required to be true to their users and use authentic information on their pages. The nature of information is also important. An example can be of a laptop selling online company, which presents highly technical information that is not understandable for majority of people, or an online pharmacy that uses complex biological terms, which does not let 
people identify the medicine they are looking for. Most respondents strongly agreed that the nature of provided information plays a vital role when it comes to consumer behavior.

\subsection{Ethics}

The reviews of other customers along with their pictures were ethically unacceptable by most people due to privacy concerns. However, the standard deviation from the mean was found to be 1.3279 , which implies that consumers also rely on reviews of the products or services of a business while purchasing from the SMEs. Meanwhile, when SMEs use content from other sources and do not give credit or inscribe the source of data, it leads to a distrust of the image of the brand. On the other hand, when SMEs ask for personal information, people hesitate to provide such information as they believe their data can be leaked or the data can be breached if the SMEs have not implemented strong security for their information system. However, most of the respondents had neutral views over the question with the mean being 3 while the standard deviation is 1.099 .

\subsection{Social}

Consumers rely on the reviews, ratings and comments of other consumers for making a purchase. When SMEs provide options to the customers to freely express their views about the business, its services, and its products, it raises a sense of trust for new customers. The mean of 1.63 represents that most respondents have strongly agreed or agreed over the statement. Additionally, the response for the user generated queries, suggestions made by consumers or concerns regarding the products or services, when answered by the representatives of the business, leads to the positive impression of the business. This leads to positive consumer behavior towards the business as consumers consider the attention given to them identical to quality service of the business. On the other hand, SMEs offering other services like giveaways and events to launch and market their products, affects consumer perceptions in a positive way. This was denoted with a mean of 1.79 with standard deviation of 0.86 . When these SMEs post the offers on social media that targets consumer needs, most people agree that it does persuade them to purchase from them with a mean value of 2.04. However, a majority of consumers think that SMEs limited to few delivery options on social media are likely to lose consumers as they hesitate to purchase an item that has to be imported from other countries to due high shipment and delivery costs. This was represented by a mean value of 1.94 .

\subsection{Security}

When SMEs share their privacy and security policies with the consumers, it creates a reliable image of the business for the buyers. This factor leads to visibility and clarity of information which consumers seeks to be provided with. The mean value of 1.686667 clearly denotes that people are attracted to clarity of information due to trust issues related to their information. Thus, security is an important aspect of e-commerce. Most people do not like their data to be shared with third party as they fear of data breach and violation of data. The mean value for the statement that SMEs restricting sharing personal information to third party positively influences consumer behavior was found to be 1.813333 with a standard deviation value of 0.745336 . Most of the people believe in cash on delivery options even today, due to the breach of the information of credit cards through online payment methods. Thus, majority of customers feel safe with the cash on delivery method. It provides them more than one benefit as transactional data or credit card information remains secure. Secondly, it secures value for money as people can see the product before paying for it, rather than paying before and getting the product later. Thus, a wide range of the population believes that SMEs promoting their products using variety of payment options are likely to gain more consumer attention, with a mean of 1.886667 and standard deviation value of 0.839756 .

\subsection{Correlation Table}

Correlation Table is below (see Table 2). 
Table 2. Correlation Table.

\begin{tabular}{|c|c|c|c|c|c|c|c|c|c|c|c|c|c|c|c|c|c|c|c|c|c|}
\hline & & DV.S. & V01 & V02 & V03 & V04 & I01 & I02 & 103 & I04 & E01 & E02 & E03 & S01 & S02 & S03 & S04 & S05 & $\mathrm{C} 01$ & $\mathrm{C} 02$ & $\mathrm{C} 03$ \\
\hline \multirow{3}{*}{ DV.S. } & $\begin{array}{c}\text { Pearson } \\
\text { Correlation }\end{array}$ & 1 & 0.007 & 0.124 & -0.055 & 0.021 & $0.190 *$ & -0.033 & -0.095 & $-0.204 *$ & -0.055 & -0.061 & $0.179 *$ & $-0.169 *$ & -0.044 & 0.037 & $0.217 * *$ & 0.018 & 0.114 & 0.044 & 0.075 \\
\hline & Sig. (2-tailed) & & 0.928 & 0.130 & 0.503 & 0.798 & 0.020 & 0.690 & 0.246 & 0.012 & 0.501 & 0.462 & 0.028 & 0.039 & 0.592 & 0.653 & 0.008 & 0.826 & 0.167 & 0.589 & 0.360 \\
\hline & $\mathrm{N}$ & 150 & 150 & 150 & 150 & 150 & 150 & 150 & 150 & 150 & 150 & 150 & 150 & 150 & 150 & 150 & 150 & 150 & 150 & 150 & 150 \\
\hline \multirow{3}{*}{ V01 } & $\begin{array}{c}\text { Pearson } \\
\text { Correlation }\end{array}$ & 0.007 & 1 & -0.100 & 0.035 & $0.168^{*}$ & -0.007 & -0.031 & 0.043 & 0.002 & -0.076 & -0.004 & -0.250 ** & 0.153 & 0.015 & -0.078 & 0.053 & -0.008 & -0.134 & -0.086 & -0.049 \\
\hline & Sig. (2-tailed) & 0.928 & & 0.221 & 0.671 & 0.040 & 0.934 & 0.704 & 0.604 & 0.983 & 0.356 & 0.957 & 0.002 & 0.062 & 0.859 & 0.345 & 0.520 & 0.920 & 0.102 & 0.293 & 0.548 \\
\hline & $\mathrm{N}$ & 150 & 150 & 150 & 150 & 150 & 150 & 150 & 150 & 150 & 150 & 150 & 150 & 150 & 150 & 150 & 150 & 150 & 150 & 150 & 150 \\
\hline \multirow{3}{*}{ V02 } & $\begin{array}{c}\text { Pearson } \\
\text { Correlation } \\
\end{array}$ & 0.124 & -0.100 & 1 & -0.044 & -0.059 & -0.165 * & -0.075 & -0.101 & -0.055 & 0.050 & -0.130 & 0.250 ** & 0.082 & -0.033 & 0.068 & -0.115 & -0.110 & 0.110 & 0.034 & -0.074 \\
\hline & Sig. (2-tailed) & 0.130 & 0.221 & & 0.593 & 0.475 & 0.044 & 0.359 & 0.217 & 0.503 & 0.544 & 0.114 & 0.002 & 0.318 & 0.690 & 0.405 & 0.160 & 0.180 & 0.179 & 0.680 & 0.369 \\
\hline & $\mathrm{N}$ & 150 & 150 & 150 & 150 & 150 & 150 & 150 & 150 & 150 & 150 & 150 & 150 & 150 & 150 & 150 & 150 & 150 & 150 & 150 & 150 \\
\hline \multirow{3}{*}{ V03 } & $\begin{array}{c}\text { Pearson } \\
\text { Correlation } \\
\end{array}$ & -0.055 & 0.035 & -0.044 & 1 & $0.267^{* *}$ & $0.196 *$ & 0.062 & 0.056 & -0.201 * & -0.192 * & $0.222 * *$ & -0.058 & -0.019 & -0.038 & -0.141 & 0.081 & 0.100 & 0.081 & 0.020 & 0.125 \\
\hline & Sig. (2-tailed) & 0.503 & 0.671 & 0.593 & & 0.001 & 0.016 & 0.450 & 0.497 & 0.014 & 0.018 & 0.006 & 0.485 & 0.813 & 0.641 & 0.086 & 0.324 & 0.224 & 0.326 & 0.805 & 0.128 \\
\hline & $\mathrm{N}$ & 150 & 150 & 150 & 150 & 150 & 150 & 150 & 150 & 150 & 150 & 150 & 150 & 150 & 150 & 150 & 150 & 150 & 150 & 150 & 150 \\
\hline \multirow{3}{*}{ V04 } & $\begin{array}{c}\text { Pearson } \\
\text { Correlation } \\
\end{array}$ & 0.021 & $0.168^{*}$ & -0.059 & 0.267 ** & 1 & 0.036 & 0.025 & 0.074 & $-0.197^{*}$ & -0.052 & -0.020 & -0.205 * & 0.040 & -0.017 & -0.029 & -0.103 & -0.013 & 0.009 & 0.062 & -0.026 \\
\hline & Sig. (2-tailed) & 0.798 & 0.040 & 0.475 & 0.001 & & 0.662 & 0.762 & 0.369 & 0.016 & 0.530 & 0.806 & 0.012 & 0.627 & 0.832 & 0.721 & 0.212 & 0.875 & 0.918 & 0.452 & 0.749 \\
\hline & $\mathrm{N}$ & 150 & 150 & 150 & 150 & 150 & 150 & 150 & 150 & 150 & 150 & 150 & 150 & 150 & 150 & 150 & 150 & 150 & 150 & 150 & 150 \\
\hline \multirow{3}{*}{ I01 } & $\begin{array}{c}\text { Pearson } \\
\text { Correlation } \\
\end{array}$ & $0.190 *$ & -0.007 & -0.165 * & $0.196 *$ & 0.036 & 1 & -0.157 & 0.045 & 0.006 & -0.111 & -0.041 & -0.069 & -0.054 & -0.111 & 0.092 & $0.235^{* *}$ & 0.140 & 0.123 & 0.045 & 0.151 \\
\hline & Sig. (2-tailed) & 0.020 & 0.934 & 0.044 & 0.016 & 0.662 & & 0.055 & 0.584 & 0.940 & 0.178 & 0.622 & 0.404 & 0.508 & 0.177 & 0.262 & 0.004 & 0.087 & 0.133 & 0.581 & 0.064 \\
\hline & $\mathrm{N}$ & 150 & 150 & 150 & 150 & 150 & 150 & 150 & 150 & 150 & 150 & 150 & 150 & 150 & 150 & 150 & 150 & 150 & 150 & 150 & 150 \\
\hline \multirow{3}{*}{$\mathrm{I} 02$} & $\begin{array}{c}\text { Pearson } \\
\text { Correlation } \\
\end{array}$ & -0.033 & -0.031 & -0.075 & 0.062 & 0.025 & -0.157 & 1 & 0.067 & -0.027 & -0.049 & 0.185 * & 0.006 & -0.071 & 0.086 & -0.014 & 0.043 & -0.021 & 0.087 & 0.022 & 0.122 \\
\hline & Sig. (2-tailed) & 0.690 & 0.704 & 0.359 & 0.450 & 0.762 & 0.055 & & 0.413 & 0.739 & 0.554 & 0.024 & 0.940 & 0.387 & 0.295 & 0.861 & 0.601 & 0.801 & 0.288 & 0.786 & 0.136 \\
\hline & $\mathrm{N}$ & 150 & 150 & 150 & 150 & 150 & 150 & 150 & 150 & 150 & 150 & 150 & 150 & 150 & 150 & 150 & 150 & 150 & 150 & 150 & 150 \\
\hline \multirow{3}{*}{$\mathrm{I} 03$} & $\begin{array}{c}\text { Pearson } \\
\text { Correlation }\end{array}$ & -0.095 & 0.043 & -0.101 & 0.056 & 0.074 & 0.045 & 0.067 & 1 & -0.041 & 0.053 & 0.077 & -0.132 & -0.041 & 0.017 & -0.143 & 0.112 & 0.053 & 0.043 & -0.166 * & 0.022 \\
\hline & Sig. (2-tailed) & 0.246 & 0.604 & 0.217 & 0.497 & 0.369 & 0.584 & 0.413 & & 0.616 & 0.519 & 0.351 & 0.109 & 0.615 & 0.837 & 0.081 & 0.173 & 0.521 & 0.601 & 0.042 & 0.787 \\
\hline & $\mathrm{N}$ & 150 & 150 & 150 & 150 & 150 & 150 & 150 & 150 & 150 & 150 & 150 & 150 & 150 & 150 & 150 & 150 & 150 & 150 & 150 & 150 \\
\hline \multirow{3}{*}{$\mathrm{I} 04$} & $\begin{array}{c}\text { Pearson } \\
\text { Correlation }\end{array}$ & $-0.204 *$ & 0.002 & -0.055 & -0.201 * & -0.197 * & 0.006 & -0.027 & -0.041 & 1 & 0.155 & -0.049 & -0.095 & -0.127 & 0.017 & -0.046 & -0.057 & 0.077 & -0.082 & 0.005 & 0.094 \\
\hline & Sig. (2-tailed) & 0.012 & 0.983 & 0.503 & 0.014 & 0.016 & 0.940 & 0.739 & 0.616 & & 0.059 & 0.551 & 0.247 & 0.121 & 0.832 & 0.577 & 0.492 & 0.352 & 0.321 & 0.951 & 0.253 \\
\hline & $\mathrm{N}$ & 150 & 150 & 150 & 150 & 150 & 150 & 150 & 150 & 150 & 150 & 150 & 150 & 150 & 150 & 150 & 150 & 150 & 150 & 150 & 150 \\
\hline
\end{tabular}


Table 2. Cont.

\begin{tabular}{|c|c|c|c|c|c|c|c|c|c|c|c|c|c|c|c|c|c|c|c|c|c|}
\hline & & DV.s. & V01 & V02 & v03 & V04 & I01 & 102 & I03 & I04 & E01 & E02 & E03 & S01 & S02 & S03 & S04 & S05 & $\mathrm{C} 01$ & $\mathrm{C} 02$ & $\mathrm{C} 03$ \\
\hline \multirow{3}{*}{ E01 } & $\begin{array}{c}\text { Pearson } \\
\text { Correlation }\end{array}$ & -0.055 & -0.076 & 0.050 & -0.192 * & -0.052 & -0.111 & -0.049 & 0.053 & 0.155 & 1 & -0.042 & -0.041 & 0.049 & -0.082 & -0.001 & -0.076 & -0.047 & 0.005 & $-0.195 *$ & -0.131 \\
\hline & Sig. (2-tailed) & 0.501 & 0.356 & 0.544 & 0.018 & 0.530 & 0.178 & 0.554 & 0.519 & 0.059 & & 0.613 & 0.615 & 0.553 & 0.317 & 0.988 & 0.356 & 0.570 & 0.950 & 0.017 & 0.109 \\
\hline & $\mathrm{N}$ & 150 & 150 & 150 & 150 & 150 & 150 & 150 & 150 & 150 & 150 & 150 & 150 & 150 & 150 & 150 & 150 & 150 & 150 & 150 & 150 \\
\hline \multirow{3}{*}{ E02 } & $\begin{array}{c}\text { Pearson } \\
\text { Correlation } \\
\end{array}$ & -0.061 & -0.004 & -0.130 & 0.222 ** & -0.020 & -0.041 & 0.185 * & 0.077 & -0.049 & -0.042 & 1 & -0.137 & -0.073 & 0.047 & -0.049 & 0.141 & -0.094 & -0.112 & -0.156 & 0.036 \\
\hline & Sig. (2-tailed) & 0.462 & 0.957 & 0.114 & 0.006 & 0.806 & 0.622 & 0.024 & 0.351 & 0.551 & 0.613 & & 0.096 & 0.372 & 0.568 & 0.554 & 0.086 & 0.253 & 0.174 & 0.057 & 0.659 \\
\hline & $\mathrm{N}$ & 150 & 150 & 150 & 150 & 150 & 150 & 150 & 150 & 150 & 150 & 150 & 150 & 150 & 150 & 150 & 150 & 150 & 150 & 150 & 150 \\
\hline \multirow{3}{*}{ E03 } & $\begin{array}{c}\text { Pearson } \\
\text { Correlation } \\
\end{array}$ & 0.179 * & -0.250 ** & $0.250 * *$ & -0.058 & -0.205 * & -0.069 & 0.006 & -0.132 & -0.095 & -0.041 & -0.137 & 1 & -0.066 & -0.065 & -0.028 & -0.028 & 0.109 & 0.065 & 0.000 & -0.058 \\
\hline & Sig. (2-tailed) & 0.028 & 0.002 & 0.002 & 0.485 & 0.012 & 0.404 & 0.940 & 0.109 & 0.247 & 0.615 & 0.096 & & 0.424 & 0.431 & 0.731 & 0.734 & 0.186 & 0.430 & 1.000 & 0.480 \\
\hline & $\mathrm{N}$ & 150 & 150 & 150 & 150 & 150 & 150 & 150 & 150 & 150 & 150 & 150 & 150 & 150 & 150 & 150 & 150 & 150 & 150 & 150 & 150 \\
\hline \multirow{3}{*}{ S01 } & $\begin{array}{c}\text { Pearson } \\
\text { Correlation }\end{array}$ & $-0.169 *$ & 0.153 & 0.082 & -0.019 & 0.040 & -0.054 & -0.071 & -0.041 & -0.127 & 0.049 & -0.073 & -0.066 & 1 & 0.076 & 0.104 & -0.069 & -0.130 & -0.031 & -0.031 & -0.052 \\
\hline & Sig. (2-tailed) & 0.039 & 0.062 & 0.318 & 0.813 & 0.627 & 0.508 & 0.387 & 0.615 & 0.121 & 0.553 & 0.372 & 0.424 & & 0.357 & 0.207 & 0.404 & 0.113 & 0.709 & 0.703 & 0.527 \\
\hline & $\mathrm{N}$ & 150 & 150 & 150 & 150 & 150 & 150 & 150 & 150 & 150 & 150 & 150 & 150 & 150 & 150 & 150 & 150 & 150 & 150 & 150 & 150 \\
\hline \multirow{3}{*}{ S02 } & $\begin{array}{c}\text { Pearson } \\
\text { Correlation } \\
\end{array}$ & -0.044 & 0.015 & -0.033 & -0.038 & -0.017 & -0.111 & 0.086 & 0.017 & 0.017 & -0.082 & 0.047 & -0.065 & 0.076 & 1 & -0.016 & 0.037 & -0.128 & 0.064 & 0.010 & 0.009 \\
\hline & Sig. (2-tailed) & 0.592 & 0.859 & 0.690 & 0.641 & 0.832 & 0.177 & 0.295 & 0.837 & 0.832 & 0.317 & 0.568 & 0.431 & 0.357 & & 0.845 & 0.651 & 0.119 & 0.433 & 0.903 & 0.910 \\
\hline & $\mathrm{N}$ & 150 & 150 & 150 & 150 & 150 & 150 & 150 & 150 & 150 & 150 & 150 & 150 & 150 & 150 & 150 & 150 & 150 & 150 & 150 & 150 \\
\hline \multirow{3}{*}{ S03 } & $\begin{array}{c}\text { Pearson } \\
\text { Correlation }\end{array}$ & 0.037 & -0.078 & 0.068 & -0.141 & -0.029 & 0.092 & -0.014 & -0.143 & -0.046 & -0.001 & -0.049 & -0.028 & 0.104 & -0.016 & 1 & -0.007 & -0.120 & -0.152 & 0.044 & -0.079 \\
\hline & Sig. (2-tailed) & 0.653 & 0.345 & 0.405 & 0.086 & 0.721 & 0.262 & 0.861 & 0.081 & 0.577 & 0.988 & 0.554 & 0.731 & 0.207 & 0.845 & & 0.934 & 0.143 & 0.063 & 0.593 & 0.337 \\
\hline & $\mathrm{N}$ & 150 & 150 & 150 & 150 & 150 & 150 & 150 & 150 & 150 & 150 & 150 & 150 & 150 & 150 & 150 & 150 & 150 & 150 & 150 & 150 \\
\hline \multirow{3}{*}{ S04 } & $\begin{array}{c}\text { Pearson } \\
\text { Correlation } \\
\end{array}$ & $0.217^{* *}$ & 0.053 & -0.115 & 0.081 & -0.103 & 0.235 ** & 0.043 & 0.112 & -0.057 & -0.076 & 0.141 & -0.028 & -0.069 & 0.037 & -0.007 & 1 & 0.140 & 0.101 & -0.143 & 0.125 \\
\hline & Sig. (2-tailed) & 0.008 & 0.520 & 0.160 & 0.324 & 0.212 & 0.004 & 0.601 & 0.173 & 0.492 & 0.356 & 0.086 & 0.734 & 0.404 & 0.651 & 0.934 & & 0.088 & 0.219 & 0.081 & 0.127 \\
\hline & $\mathrm{N}$ & 150 & 150 & 150 & 150 & 150 & 150 & 150 & 150 & 150 & 150 & 150 & 150 & 150 & 150 & 150 & 150 & 150 & 150 & 150 & 150 \\
\hline \multirow{3}{*}{ S05 } & $\begin{array}{c}\text { Pearson } \\
\text { Correlation }\end{array}$ & 0.018 & -0.008 & -0.110 & 0.100 & -0.013 & 0.140 & -0.021 & 0.053 & 0.077 & -0.047 & -0.094 & 0.109 & -0.130 & -0.128 & -0.120 & 0.140 & 1 & -0.008 & -0.017 & 0.009 \\
\hline & Sig. (2-tailed) & 0.826 & 0.920 & 0.180 & 0.224 & 0.875 & 0.087 & 0.801 & 0.521 & 0.352 & 0.570 & 0.253 & 0.186 & 0.113 & 0.119 & 0.143 & 0.088 & & 0.921 & 0.838 & 0.916 \\
\hline & $\mathrm{N}$ & 150 & 150 & 150 & 150 & 150 & 150 & 150 & 150 & 150 & 150 & 150 & 150 & 150 & 150 & 150 & 150 & 150 & 150 & 150 & 150 \\
\hline \multirow{3}{*}{$\mathrm{C} 01$} & $\begin{array}{c}\text { Pearson } \\
\text { Correlation }\end{array}$ & 0.114 & -0.134 & 0.110 & 0.081 & 0.009 & 0.123 & 0.087 & 0.043 & -0.082 & 0.005 & -0.112 & 0.065 & -0.031 & 0.064 & -0.152 & 0.101 & -0.008 & 1 & 0.158 & -0.035 \\
\hline & Sig. (2-tailed) & 0.167 & 0.102 & 0.179 & 0.326 & 0.918 & 0.133 & 0.288 & 0.601 & 0.321 & 0.950 & 0.174 & 0.430 & 0.709 & 0.433 & 0.063 & 0.219 & 0.921 & & 0.053 & 0.668 \\
\hline & $\mathrm{N}$ & 150 & 150 & 150 & 150 & 150 & 150 & 150 & 150 & 150 & 150 & 150 & 150 & 150 & 150 & 150 & 150 & 150 & 150 & 150 & 150 \\
\hline \multirow{3}{*}{$\mathrm{C} 02$} & $\begin{array}{c}\text { Pearson } \\
\text { Correlation }\end{array}$ & 0.044 & -0.086 & 0.034 & 0.020 & 0.062 & 0.045 & 0.022 & $-0.166 *$ & 0.005 & $-0.195 *$ & -0.156 & 0.000 & -0.031 & 0.010 & 0.044 & -0.143 & -0.017 & 0.158 & 1 & 0.202 \\
\hline & Sig. (2-tailed) & 0.589 & 0.293 & 0.680 & 0.805 & 0.452 & 0.581 & 0.786 & 0.042 & 0.951 & 0.017 & 0.057 & 1.000 & 0.703 & 0.903 & 0.593 & 0.081 & 0.838 & 0.053 & & 0.013 \\
\hline & $\mathrm{N}$ & 150 & 150 & 150 & 150 & 150 & 150 & 150 & 150 & 150 & 150 & 150 & 150 & 150 & 150 & 150 & 150 & 150 & 150 & 150 & 150 \\
\hline \multirow{3}{*}{$\mathrm{C} 03$} & $\begin{array}{c}\text { Pearson } \\
\text { Correlation } \\
\end{array}$ & 0.075 & -0.049 & -0.074 & 0.125 & -0.026 & 0.151 & 0.122 & 0.022 & 0.094 & -0.131 & 0.036 & -0.058 & -0.052 & 0.009 & -0.079 & 0.125 & 0.009 & -0.035 & $0.202 *$ & 1 \\
\hline & Sig. (2-tailed) & 0.360 & 0.548 & 0.369 & 0.128 & 0.749 & 0.064 & 0.136 & 0.787 & 0.253 & 0.109 & 0.659 & 0.480 & 0.527 & 0.910 & 0.337 & 0.127 & 0.916 & 0.668 & 0.013 & \\
\hline & $\mathrm{N}$ & 150 & 150 & 150 & 150 & 150 & 150 & 150 & 150 & 150 & 150 & 150 & 150 & 150 & 150 & 150 & 150 & 150 & 150 & 150 & 150 \\
\hline
\end{tabular}

*. Correlation is significant at the 0.05 level (2-tailed); ${ }^{* *}$. Correlation is significant at the 0.01 level (2-tailed). 
The correlation table represents relationship between different variables of sustainability. The table uses the Pearson correlation and significant two-tailed correlation. The Pearson correlation of variables with the significant aspects of sustainability is such that SMEs fulfilling consumer needs by posting offers on social media attract consumers, is found to be most relatable aspect to sustainability. However, the nature of information does not significantly relate to sustainability of SMEs. The significant two-tailed correlation denotes that SMEs limited to few delivery options on social media are likely to lose consumers when it comes to sustainability.

\subsection{Reliability}

Reliability as in Table 3 represents stability or regularity within time (test-retest reliability) and within items (internal consistency). The reliability is test is done based on the Cronbach's alpha. On the other hand, validity provides the degree to which the scores actually denote the specified variable. Thus, the reliability table represents the regularity of each variable along with correlation with each other.

Table 3. Reliability statistics.

\begin{tabular}{|c|c|c|c|c|c|c|c|c|c|c|c|c|c|c|c|c|c|c|c|c|}
\hline & DV.S & V01 & V02 & V03 & V04 & I01 & I02 & 103 & I04 & E01 & E02 & E03 & S01 & S02 & S03 & S04 & S05 & C01 & $\mathrm{C} 02$ & $\mathrm{C} 03$ \\
\hline DV.S. & 1.000 & 0.007 & 0.124 & -0.055 & 0.021 & 0.190 & -0.033 & -0.095 & -0.204 & -0.055 & -0.061 & 0.179 & -0.169 & -0.044 & 0.037 & 0.217 & 0.018 & 0.114 & 0.044 & 0.075 \\
\hline V01 & 0.007 & 1.000 & -0.100 & 0.035 & 0.168 & -0.007 & -0.031 & 0.043 & 0.002 & -0.076 & -0.004 & -0.250 & 0.153 & 0.015 & -0.078 & 0.053 & -0.008 & -0.134 & -0.086 & -0.049 \\
\hline V02 & 0.124 & -0.100 & 1.000 & -0.044 & -0.059 & -0.165 & -0.075 & -0.101 & -0.055 & 0.050 & -0.130 & 0.250 & 0.082 & -0.033 & 0.068 & -0.115 & -0.110 & 0.110 & 0.034 & -0.074 \\
\hline V03 & -0.055 & 0.035 & -0.044 & 1.000 & 0.267 & 0.196 & 0.062 & 0.056 & -0.201 & -0.192 & 0.222 & -0.058 & -0.019 & -0.038 & -0.141 & 0.081 & 0.100 & 0.081 & 0.020 & 0.125 \\
\hline V04 & 0.021 & 0.168 & -0.059 & 0.267 & 1.000 & 0.036 & 0.025 & 0.074 & -0.197 & -0.052 & -0.020 & -0.205 & 0.040 & -0.017 & -0.029 & -0.103 & -0.013 & 0.009 & 0.062 & -0.026 \\
\hline I01 & 0.190 & -0.007 & -0.165 & 0.196 & 0.036 & 1.000 & -0.157 & 0.045 & 0.006 & -0.111 & -0.041 & -0.069 & -0.054 & -0.111 & 0.092 & 0.235 & 0.140 & 0.123 & 0.045 & 0.151 \\
\hline I02 & -0.033 & -0.031 & -0.075 & 0.062 & 0.025 & -0.157 & 1.000 & 0.067 & -0.027 & -0.049 & 0.185 & 0.006 & -0.071 & 0.086 & -0.014 & 0.043 & -0.021 & 0.087 & 0.022 & 0.122 \\
\hline I03 & -0.095 & 0.043 & -0.101 & 0.056 & 0.074 & 0.045 & 0.067 & 1.000 & -0.041 & 0.053 & 0.077 & -0.132 & -0.041 & 0.017 & -0.143 & 0.112 & 0.053 & 0.043 & -0.166 & 0.022 \\
\hline I04 & -0.204 & 0.002 & -0.055 & -0.201 & -0.197 & 0.006 & -0.027 & -0.041 & 1.000 & 0.155 & -0.049 & -0.095 & -0.127 & 0.017 & -0.046 & -0.057 & 0.077 & -0.082 & 0.005 & 0.094 \\
\hline E01 & -0.055 & -0.076 & 0.050 & -0.192 & -0.052 & -0.111 & -0.049 & 0.053 & 0.155 & 1.000 & -0.042 & -0.041 & 0.049 & -0.082 & -0.001 & -0.076 & -0.047 & 0.005 & -0.195 & -0.131 \\
\hline E02 & -0.061 & -0.004 & -0.130 & 0.222 & -0.020 & -0.041 & 0.185 & 0.077 & -0.049 & -0.042 & 1.000 & -0.137 & -0.073 & 0.047 & -0.049 & 0.141 & -0.094 & -0.112 & -0.156 & 0.036 \\
\hline E03 & 0.179 & -0.250 & 0.250 & -0.058 & -0.205 & -0.069 & 0.006 & -0.132 & -0.095 & -0.041 & -0.137 & 1.000 & -0.066 & -0.065 & -0.028 & -0.028 & 0.109 & 0.065 & 0.000 & -0.058 \\
\hline S01 & -0.169 & 0.153 & 0.082 & -0.019 & 0.040 & -0.054 & -0.071 & -0.041 & -0.127 & 0.049 & -0.073 & -0.066 & 1.000 & 0.076 & 0.104 & -0.069 & -0.130 & -0.031 & -0.031 & -0.052 \\
\hline S02 & -0.044 & 0.015 & -0.033 & -0.038 & -0.017 & -0.111 & 0.086 & 0.017 & 0.017 & -0.082 & 0.047 & -0.065 & 0.076 & 1.000 & -0.016 & 0.037 & -0.128 & 0.064 & 0.010 & 0.009 \\
\hline S03 & 0.037 & -0.078 & 0.068 & -0.141 & -0.029 & 0.092 & -0.014 & -0.143 & -0.046 & -0.001 & -0.049 & -0.028 & 0.104 & -0.016 & 1.000 & -0.007 & -0.120 & -0.152 & 0.044 & -0.079 \\
\hline S04 & 0.217 & 0.053 & -0.115 & 0.081 & -0.103 & 0.235 & 0.043 & 0.112 & -0.057 & -0.076 & 0.141 & -0.028 & -0.069 & 0.037 & -0.007 & 1.000 & 0.140 & 0.101 & -0.143 & 0.125 \\
\hline S05 & 0.018 & -0.008 & -0.110 & 0.100 & -0.013 & 0.140 & -0.021 & 0.053 & 0.077 & -0.047 & -0.094 & 0.109 & -0.130 & -0.128 & -0.120 & 0.140 & 1.000 & -0.008 & -0.017 & 0.009 \\
\hline $\mathrm{C} 01$ & 0.114 & -0.134 & 0.110 & 0.081 & 0.009 & 0.123 & 0.087 & 0.043 & -0.082 & 0.005 & -0.112 & 0.065 & -0.031 & 0.064 & -0.152 & 0.101 & -0.008 & 1.000 & 0.158 & -0.035 \\
\hline $\mathrm{C} 02$ & 0.044 & -0.086 & 0.034 & 0.020 & 0.062 & 0.045 & 0.022 & -0.166 & 0.005 & -0.195 & -0.156 & 0.000 & -0.031 & 0.010 & 0.044 & -0.143 & -0.017 & 0.158 & 1.000 & 0.202 \\
\hline $\mathrm{C} 03$ & 0.075 & -0.049 & -0.074 & 0.125 & -0.026 & 0.151 & 0.122 & 0.022 & 0.094 & -0.131 & 0.036 & -0.058 & -0.052 & 0.009 & -0.079 & 0.125 & 0.009 & -0.035 & 0.202 & 1.000 \\
\hline
\end{tabular}

\subsection{Validity}

The validity in Table 4 represents values of variables i.e., visuals, information, ethics, social, security; with the relation of aspects of sustainability.

Table 4. Validity statistics.

\begin{tabular}{cccccc}
\hline & $\begin{array}{c}\text { Scale Mean if Item } \\
\text { Deleted }\end{array}$ & $\begin{array}{c}\text { Scale Variance if } \\
\text { Item Deleted }\end{array}$ & $\begin{array}{c}\text { Corrected Item-Total } \\
\text { Correlation }\end{array}$ & $\begin{array}{c}\text { Squared Multiple } \\
\text { Correlation }\end{array}$ & $\begin{array}{c}\text { Cronbach's Alpha if } \\
\text { Item Deleted }\end{array}$ \\
\hline DV.S & 45.32 & 14.259 & 0.107 & 0.234 & $-0.135^{\text {a }}$ \\
\hline V01 & 46.35 & 16.915 & -0.095 & 0.159 & 0.001 \\
\hline V02 & 46.55 & 16.907 & -0.068 & 0.167 & $-0.018^{\text {a }}$ \\
\hline V03 & 44.43 & 14.999 & 0.119 & 0.260 & $-0.121^{\text {a }}$ \\
\hline V04 & 46.41 & 16.229 & 0.010 & 0.188 & $-0.053^{\text {a }}$ \\
\hline
\end{tabular}


Table 4. Cont.

\begin{tabular}{lccccc}
\hline & $\begin{array}{c}\text { Scale Mean if Item } \\
\text { Deleted }\end{array}$ & $\begin{array}{c}\text { Scale Variance if } \\
\text { Item Deleted }\end{array}$ & $\begin{array}{c}\text { Corrected Item-Total } \\
\text { Correlation }\end{array}$ & $\begin{array}{c}\text { Squared Multiple } \\
\text { Correlation }\end{array}$ & $\begin{array}{c}\text { Cronbach's Alpha if } \\
\text { Item Deleted }\end{array}$ \\
\hline I01 & 46.08 & 14.208 & 0.143 & 0.249 & $-0.155^{\text {a }}$ \\
\hline I02 & 44.65 & 15.921 & 0.029 & 0.120 & $-0.065^{\text {a }}$ \\
\hline I03 & 44.21 & 16.353 & -0.003 & 0.103 & $-0.046^{\text {a }}$ \\
\hline I04 & 46.61 & 17.688 & -0.184 & 0.202 & 0.015 \\
\hline E01 & 45.05 & 17.642 & -0.206 & 0.139 & 0.093 \\
\hline E02 & 44.10 & 16.601 & -0.049 & 0.188 & $0.023^{\text {a }}$ \\
\hline E03 & 45.23 & 17.053 & -0.127 & 0.228 & -0.025 \\
\hline S01 & 46.60 & 17.275 & -0.109 & 0.136 & $-0.024^{\text {a }}$ \\
\hline S02 & 46.60 & 17.034 & -0.067 & 0.064 & 0.006 \\
\hline S03 & 46.44 & 17.201 & -0.117 & 0.141 & $-0.153^{\text {a }}$ \\
\hline S04 & 46.19 & 14.922 & 0.210 & 0.204 & $-0.058^{\text {a }}$ \\
\hline S05 & 46.29 & 16.155 & 0.020 & 0.127 & $-0.096^{\text {a }}$ \\
\hline C01 & 46.55 & 15.847 & 0.116 & 0.177 & $-0.026^{\text {a }}$ \\
\hline C02 & 46.42 & 16.876 & -0.053 & 0.185 & $-0.099^{\text {a }}$ \\
\hline C03 & 46.35 & 15.678 & 0.109 & 0.158 & \\
\hline
\end{tabular}

a. Dependent Variable: Which of the following aspect of sustainable marketing strategy impacts consumer behavior?

Table 5 overall represents the validity scale statistics.

Table 5. Validity scale statistics.

\begin{tabular}{cccc}
\hline Mean & Variance & Std. Deviation & N of Items \\
\hline 48.23 & 17.106 & 4.136 & 20 \\
\hline
\end{tabular}

\subsection{Regression}

Table 6 represents the ANOVA ${ }^{\text {a }}$ table for test results.

Table 6. ANOVA ${ }^{\text {a }}$ table for test results.

\begin{tabular}{ccccccc}
\hline & Model & Sum of Squares & df & Mean Square & F & Sig. \\
\hline \multirow{2}{*}{$\mathbf{1}$} & Regression & 61.643 & 19 & 3.244 & 2.086 & $0.008^{\mathrm{b}}$ \\
& Residual & 202.230 & 130 & 1.556 & & \\
& Total & 263.873 & 149 & & & \\
\hline
\end{tabular}

a. Dependent Variable: Which of the following aspect of sustainable marketing strategy impacts consumer behavior? b. Predictors: (Constant), SMEs promoting their products using variety of payment options are likely to gain more consumer attention; SMEs limited to few delivery options on social media are likely to lose consumers; Use of attractive images and limited content positively impacts consumer perceptions; Sharing security and privacy policy strengthens organization-consumer relationship; Information on social media is quite helpful for letting consumers to take positive decisions; Active customer support and responses to queries enable consumers to give more attention to the business; SMEs open for reviews on social media positively affects consumer behavior; Sharing consumer reviews and their pictures on social media is ethically acceptable to attract other consumers; SMEs uses accurate information for their targeted consumers to promote their products online; Use of engaging colors and graphics adds visual impression on consumers; SMEs launching giveaways and events to promote their products highly affect consumer perceptions; SMEs fulfilling consumer needs by posting offers on social media attract consumers a lot; An attractive layout of social media influences consumers to approach a business; Using information from other sources without giving credits affect consumer perceptions; Consumer behavior depends on the nature of information provided by SMEs on social media websites and pages; SMEs that restrict sharing of personal information to a third party positively influences consumer behavior; Up-to-date information increases chances of more consumer attention; SMEs asking for personal information for their organizational operations are ethically inappropriate and significantly affects consumers; SMEs use pleasing designs for promoting their products.

Linear regression is the secondary step of research that assists with the prediction of variables based on the value of the other variables. The regression is done in Table 7 against the aspects of sustainable marketing strategy for SMEs that impacts consumer behavior. 
Table 7. Regression coefficients.

\begin{tabular}{|c|c|c|c|c|c|c|}
\hline & \multirow[t]{2}{*}{ Model } & \multicolumn{2}{|c|}{$\begin{array}{c}\text { Unstandardized } \\
\text { Coefficients }\end{array}$} & \multirow{2}{*}{$\begin{array}{c}\begin{array}{l}\text { Standardized } \\
\text { Coefficients }\end{array} \\
\text { Beta }\end{array}$} & \multirow[t]{2}{*}{$\mathbf{t}$} & \multirow[t]{2}{*}{ Sig. } \\
\hline & & B & Std. Error & & & \\
\hline \multirow{20}{*}{1} & (Constant) & 3.120 & 1.387 & & 2.249 & 0.026 \\
\hline & V01 & 0.126 & 0.114 & 0.092 & 1.109 & 0.269 \\
\hline & V02 & 0.217 & 0.138 & 0.131 & 1.578 & 0.117 \\
\hline & V03 & -0.204 & 0.110 & -0.163 & -1.845 & 0.067 \\
\hline & V04 & 0.107 & 0.126 & 0.072 & 0.848 & 0.398 \\
\hline & I01 & 0.195 & 0.093 & 0.183 & 2.097 & 0.038 \\
\hline & I02 & -0.024 & 0.111 & -0.018 & -0.214 & 0.831 \\
\hline & I03 & -0.162 & 0.122 & -0.108 & -1.336 & 0.184 \\
\hline & I04 & -0.473 & 0.173 & -0.228 & -2.727 & 0.007 \\
\hline & E01 & 0.021 & 0.083 & 0.021 & 0.249 & 0.804 \\
\hline & E02 & -0.019 & 0.121 & -0.014 & -0.160 & 0.873 \\
\hline & E03 & 0.177 & 0.105 & 0.146 & 1.689 & 0.094 \\
\hline & S01 & -0.411 & 0.165 & -0.201 & -2.486 & 0.014 \\
\hline & S02 & -0.011 & 0.160 & -0.006 & -0.070 & 0.945 \\
\hline & S03 & 0.014 & 0.128 & 0.009 & 0.107 & 0.915 \\
\hline & S04 & 0.285 & 0.129 & 0.187 & 2.219 & 0.028 \\
\hline & S05 & -0.030 & 0.122 & -0.020 & -0.249 & 0.804 \\
\hline & $\mathrm{C} 01$ & 0.097 & 0.150 & 0.055 & 0.646 & 0.520 \\
\hline & $\mathrm{C} 02$ & 0.032 & 0.152 & 0.018 & 0.209 & 0.835 \\
\hline & $\mathrm{C} 03$ & 0.138 & 0.132 & 0.087 & 1.045 & 0.298 \\
\hline
\end{tabular}

The standardized coefficient is measured in units of standard deviation.

In statistics, unstandardized coefficients are the 'raw' coefficients produced by regression analysis when the analysis is done on original, unstandardized variables. Unlike standardized coefficients, which are normalized unit-less coefficients, an unstandardized coefficient has units and a 'real life' scale

Standardized regression of coefficients is also known as the beta weights or beta coefficients in statistics. These are the calculations in Table 7 that are derived after the analysis of regression that are standardized such that the independent as well as the dependent variables acquire variance of 1 .

\subsection{Mediation}

In Table 8 tolerance and the variance inflation factor (VIF) in mediation are two collinearity diagnostic factors that can help to identify multicollinearity. Multicollinearity is a problem that occurs with regression analysis when there is a high correlation of at least one independent variable with a combination of the other independent variables.

Table 8. Mediation coefficients.

\begin{tabular}{|c|c|c|c|c|c|c|c|c|c|c|c|}
\hline & \multirow[t]{2}{*}{ Model } & \multicolumn{2}{|c|}{$\begin{array}{c}\text { Unstandardized } \\
\text { Coefficients }\end{array}$} & \multirow{2}{*}{\multicolumn{2}{|c|}{$\begin{array}{l}\text { Standardized } \\
\text { Coefficientst }\end{array}$}} & \multirow[t]{2}{*}{ Sig. } & \multicolumn{3}{|c|}{ Correlations } & \multicolumn{2}{|c|}{$\begin{array}{l}\text { Collinearity } \\
\text { Statistics }\end{array}$} \\
\hline & & B & Std. Error & & & & Zero-order & Partial & Part & Tolerance & VIF \\
\hline \multirow{20}{*}{1} & (Constant) & 3.120 & 1.387 & & 2.249 & 0.026 & & & & & \\
\hline & V01 & 0.126 & 0.114 & 0.092 & 1.109 & 0.269 & 0.007 & 0.097 & 0.085 & 0.849 & 1.177 \\
\hline & V02 & 0.217 & 0.138 & 0.131 & 1.578 & 0.117 & 0.124 & 0.137 & 0.121 & 0.849 & 1.177 \\
\hline & V03 & -0.204 & 0.110 & -0.163 & -1.845 & 0.067 & -0.055 & -0.160 & -0.142 & 0.760 & 1.316 \\
\hline & V04 & 0.107 & 0.126 & 0.072 & 0.848 & 0.398 & 0.021 & 0.074 & 0.065 & 0.817 & 1.224 \\
\hline & I01 & 0.195 & 0.093 & 0.183 & 2.097 & 0.038 & 0.190 & 0.181 & 0.161 & 0.776 & 1.288 \\
\hline & $\mathrm{I} 02$ & -0.024 & 0.111 & -0.018 & -0.214 & 0.831 & -0.033 & -0.019 & -0.016 & 0.881 & 1.136 \\
\hline & I03 & -0.162 & 0.122 & -0.108 & -1.336 & 0.184 & -0.095 & -0.116 & -0.103 & 0.909 & 1.100 \\
\hline & I04 & -0.473 & 0.173 & -0.228 & -2.727 & 0.007 & -0.204 & -0.233 & -0.209 & 0.844 & 1.185 \\
\hline & E01 & 0.021 & 0.083 & 0.021 & 0.249 & 0.804 & -0.055 & 0.022 & 0.019 & 0.861 & 1.161 \\
\hline & E02 & -0.019 & 0.121 & -0.014 & -0.160 & 0.873 & -0.061 & -0.014 & -0.012 & 0.812 & 1.231 \\
\hline & E03 & 0.177 & 0.105 & 0.146 & 1.689 & 0.094 & 0.179 & 0.147 & 0.130 & 0.789 & 1.268 \\
\hline & S01 & -0.411 & 0.165 & -0.201 & -2.486 & 0.014 & -0.169 & -0.213 & -0.191 & 0.905 & 1.105 \\
\hline & S02 & -0.011 & 0.160 & -0.006 & -0.070 & 0.945 & -0.044 & -0.006 & -0.005 & 0.936 & 1.069 \\
\hline & S03 & 0.014 & 0.128 & 0.009 & 0.107 & 0.915 & 0.037 & 0.009 & 0.008 & 0.859 & 1.164 \\
\hline & S04 & 0.285 & 0.129 & 0.187 & 2.219 & 0.028 & 0.217 & 0.191 & 0.170 & 0.826 & 1.211 \\
\hline & S05 & -0.030 & 0.122 & -0.020 & -0.249 & 0.804 & 0.018 & -0.022 & -0.019 & 0.873 & 1.145 \\
\hline & $\mathrm{C} 01$ & 0.097 & 0.150 & 0.055 & 0.646 & 0.520 & 0.114 & 0.057 & 0.050 & 0.826 & 1.211 \\
\hline & $\mathrm{C} 02$ & 0.032 & 0.152 & 0.018 & 0.209 & 0.835 & 0.044 & 0.018 & 0.016 & 0.815 & 1.227 \\
\hline & $\mathrm{C} 03$ & 0.138 & 0.132 & 0.087 & 1.045 & 0.298 & 0.075 & 0.091 & 0.080 & 0.849 & 1.177 \\
\hline
\end{tabular}


Table 9 represents the Residual statistics.

Table 9. Residual statistics.

\begin{tabular}{lccccc}
\hline & Minimum & Maximum & Mean & Std. Deviation & N \\
\hline Predicted Value & 0.87 & 4.61 & 2.91 & 0.643 & 150 \\
Residual & -2.614 & 2.820 & 0.000 & 1.165 & 150 \\
Std. Predicted & -3.182 & 2.645 & 0.000 & 1.000 & 150 \\
$\quad$ Value & -2.096 & 2.261 & 0.000 & 0.934 & 150 \\
Std. Residual & & &
\end{tabular}

\section{Discussion}

By analyzing the data collected from the respective participants, it is investigated that consumers are mainly concerned about the outlook and features of social media pages. In the light of SMEs and their online services, almost all consumers tend to look for specific features and specifications that build their interest and thus, they are motivated to login to the specific channel more frequently. SMEs are likely to develop their social media pages and applications on the basis of consumer preferences and hence, they carry out appropriate tests and investigations in order to understand the possible factors influencing consumers' attraction towards their businesses. The hypotheses were developed and tested to ensure the accuracy of variables. These hypotheses are validated using the tests performed on collected data.

\subsection{Hypothesis 1}

Hypothesis 1 (H1). Visual cues in sustainable marketing on social media positively affect consumer behavior.

The questionnaire was designed addressing special features and some of the parameters that almost all of the consumers tend to look on different social media platforms, such as Facebook, Twitter, Instagram, LinkedIn and YouTube [18]. With respect to the questions, it is evaluated that the most pleasing factors for consumers related to social media are layouts, engaging colors and graphics, interactive designs, and attractive images [45]. From Table 2, it is interpreted that the SMEs that understand preferred choices of their targeted consumers are more likely to gain increasing attention, which guarantees organizational survival in the current competitive market.

Despite traditional marketing strategies, immense enhancements in digital media have also increased the awareness of human-computer interaction to a great extent. Thus, consumers' expectations have also increased as they tend to become familiar with the designs that satisfy their online shopping experiences [19]. However, SMEs of the current digital era are confronting numerous challenges in terms of achieving immense consumer attention due to increased digital competition as well as sustainable marketing strategies; this greatly influences consumer behavior and perception.

SMEs use sustainable marketing strategies in order to develop consumer interest by promoting their environment-friendly practices and use of organic resources [15]. Table 3 suggests that visual cues are highly associated with sustainable marketing strategies, which reflects impressive use of visual features in demonstrating products and services that are aligned with the promotion of sustainability across the market.

In this regard, different studies have also acknowledged the fact that the use of rich media and textual information on social media influences consumer perception. It was also analyzed that such marketing strategies have gained more interest of consumers as it helps them in decision-making regarding online buying [53]. Thus, the results and literature has provided much evidence about the importance of visual cues related to consumer behavior. Moreover, the interpretation of results clearly confirms that visual cues play a significant role in sustainable marketing strategies, which positively 
affects consumer behavior. To sum up, using Table 2, it is evaluated that the hypothesis is accepted as the higher Pearson correlation values determine positive consumer behavior inscribing visual cues.

\subsection{Hypothesis 2}

Hypothesis 2 (H2). Information cues in sustainable marketing on social media largely influences consumer behavior.

Information is one of the critical aspects of social media, which is used as a measure to direct attention toward a certain area. With SMEs and online businesses, information is one of the important parameters that are used in sustainable marketing strategies to increase the number of potential consumers. Table 2 shows that consumers do not have much concern regarding information cues as it does not affect their behavior. Moreover, the results also suggest that consumers pay little attention to information provided by the companies; therefore, they are not dependent on what the companies have illustrated to present their products and services [50]. However, most of the organizations tend to influence consumer interest by promoting their products and services that deviate from sustainability but, following the study, addresses that consumers take the least interest in acknowledging the information updated on online media. Hence, consumers communicated a negative response in terms of information cues, which indicates that such attributes of social media does not influence consumer behavior and their perceptions.

In a similar situation, we investigated that the role of up-to-date information and helpful concepts are also important in driving consumer interest [53]. Based on the literature and other insightful resources, it is analyzed that SMEs in the current digital age lack in providing useful information to the consumers over social media that can result in the consumers attention to deviate and thus, they shift their interest to such brands and businesses that are highly active and reliable in terms of providing related information [18]. In contrast, the responses have provided negative results, predicting past theories and literature are not addressing the mindset of present-day consumers. In Table 3, questions related to information cues were tested, which indicated unapproved responses of the participants. Also, negative Pearson correlation values in Table 2 determine that this hypothesis is rejected as consumers provided negative responses compared to the data collected from secondary sources.

\subsection{Hypothesis 3}

Hypothesis 3 (H3). Ethics cues in sustainable marketing on social media positively affect consumer behavior.

Social media comprises of different platforms where users come and share their varying experiences regarding social conduct, shopping experiences, educational advice, etc. [19]. However, some businesses take advantage of such acts. Users find it unethical to exploit their personal concerns and thus, a loss of trust is observed by the companies [47]. From the participation of the respondents and results illustrated in Table 2, it is explored that consumers have a little concern regarding ethical measures in social media. Although literature assures that a SME-consumer relationship is established on the basis of ethical measures that are being taken into consideration while promoting the businesses online, participation of respondents have given entirely opposite response. In some scenarios, consumers share their experiences and personal information with the companies, which are being used as a source to attract other consumers [15]. Such acts are considered to be unethical as it affects human rights and exploitation of consumer trust in an unethical way but with respect to Table 4, negative values of corrected item indicates that consumers have little awareness of ethical determinants, which SMEs are expected to use in their sustainable marketing strategies.

Table 2 also indicates that participants do not find ethical cues important on social media as they are more likely to consider other determinates, which are important in gaining consumer attention. 
Although, secondary sources have provided evidence that consumers are attracted to social media if ethical concerns are largely fulfilled, results gathered for following study completely oppose to what was previously explored. Thus, negative Pearson correlation values in Table 2 advocate that the stated hypothesis is rejected.

\subsection{Hypothesis 4}

Hypothesis 4 (H4). Social cues in sustainable marketing on social media effectively promotes products and services for developing positive consumer perceptions.

Social factors while developing social media layouts are considered vital as it measures the attention of users on the basis of interaction, attractiveness, likeness, and usability. In most of the cases, SMEs incorporate marketing strategies in terms of encouraging the users for developing perceptions of online shopping. However, some of the useful approaches are integrated in such a way that consumers are satisfied while their positive responses are achieved throughout their business growth [18]. With respect to sustainable marketing strategies, it is explored that most of the companies have transformed their social media by catering to consumer needs to maximize their attention and interest to the greatest level [45]. Consumer behavior is influenced only when SMEs tend to fulfill consumer needs by posting valuable information as well as offers that brings pleasure to them. Moreover, giveaways and other social activities also influence consumers emotionally due to which a maximum response is witnessed in the current competitive marketplace. The results in Table 2 emphasize positive recorded responses which ensure that the above-mentioned hypothesis is accepted.

\subsection{Hypothesis 5}

Hypothesis 5 (H5). Security cues in sustainable marketing on social media build strong relationships between SMEs and consumers.

In terms of social media, security is a crucial and important concern. Businesses have used major security controls in order to restrict information transfer from a secured channel to intruders [19]. With respect to sustainable marketing strategies, it is explored that most of the companies have transformed their social media by introducing different delivery options [12]. In this way, it has not only attracted consumers but provided an opportunity to utilize the facilities that are feasible and secured in terms of transactions as well as receiving products as mentioned on the social media platforms [15]. Furthermore, it is evaluated from Table 3 as well as that literature that the SMEs that include effective security and privacy policies in its promotions and claims are likely to receive more attention from the consumers and thus, it maintains an effective organization-consumer relationship in the market [45]. Thus, the following hypothesis is accepted based on the positive values of Pearson correlation in Table 2 as it confirms that consumer behavior is influenced with respect to security measures that are accounted in sustainable marketing strategies.

\section{Conclusions}

\subsection{Contributions to Theory and Applications}

Different theories are discussed in the study, which serves an important role in developing the understanding of significant web atmospheric cues and sustainable marketing strategies on social media. The major contribution of the study is to provide enough information regarding necessary requirements of consumers concerning online shopping and maintaining social media platforms with respect to certain important measures. From the assessment of theories and some applications incorporated in the study, it is analyzed that social media develops an impression that makes users feel 
satisfied when using its features. Moreover, the study highlights current concerns of the consumers with respect to social media. On the basis of such analysis, the study provides sufficient evidence of consumers' perceptions regarding the approaches that most of the SMEs use in their online strategies.

Based on the study, it is important to understand that web atmospheric cues in social media are vital in terms of sustainable marketing strategies to contribute to the development of positive consumer behavior. As most of these organizations perform a wide range of investigative techniques and market studies to analyze current social media trends, it becomes imperative to understand the consumer preferences play a significant role in designing interactive social media platforms that enable large audiences to interact with business organizations and significantly increases enterprise revenues. Moreover, the study contributes with providing information that would benefit SMEs in utilizing available facilities for increasing the chances of bringing a large amount of consumers to the business to increase its success.

Furthermore, theoretical aspects of the study advocate important features of social media that could be integrated in sustainable marketing strategies for promoting efficient products and services in the market. Since a number of social media platforms are used by the majority of consumers-specifically Facebook, Instagram, Twitter, YouTube, and LinkedIn - it is important to know that each platform has different performance and usability criteria on the basis of which web atmospheric cues are applied. However, consumers demand similar preferences in using each of the platforms according to their level of satisfaction and ease in optimizing decisions with respect to the use of digital media. Thus, the study ensures the importance of such atmospheric cues that must be considered while designing sustainable marketing strategies online.

\subsection{Limitations}

The following study is only based on SMEs due to their emergence in a competitive marketplace and their influence on consumers on the basis of effective marketing strategies demonstrated on social media. As SMEs are positioned in a competitive marketplace, it is important to research controlling measures, as well as effective phases of strategies that attract consumers. Furthermore, the research is only focusing on specific web atmospheric cues that are the basics in developing a vital perception of consumers regarding online businesses. Other measures are not involved in the study due to the limitation of the research area with respect to consumer preferences, as well as the need to understand the significance of web atmospheric cues in social media.

Another limitation of the study is the focus on social media platforms. Although there are a number of different social media platforms, SMEs are currently operating on the platforms with the largest amount of users. Thus, the relevance of study scope is based on the use of Facebook, Instagram, YouTube, Twitter, and LinkedIn. In addition, no specific websites or region is linked with the study due to the challenges in researching and gathering information regarding the specific area of interest. Also, consumer behavior and perceptions are targeted as it is the major force being influenced by certain web atmospheric cues on social media. However, sustainable marketing strategies are specifically used due to the lack of awareness in current business environment.

\subsection{Future Directions}

As social media has influenced the competitiveness of SMEs in the current era, it has become indispensable to implement beneficial strategies to increase the number of consumers. In this regard, such companies must keep themselves updated regarding the transformations and advancements in the field, which consumers consider important in terms of developing their interest in specific service pages. For this purpose, it requires creative teams within SMEs to understand the trending features that are related to value-generation, profitability, and building satisfaction of the consumers. Furthermore, it would be beneficial for SMEs to explore the social media platforms of their competitors in order to understand the logics and strategies they have used to influence consumer behavior at large. 
With respect to sustainable marketing strategies, SMEs are required to understand the importance of sustainability first and then introduce steps leading to promote efficient products and services in the market. In this regard, companies must undergo different monitoring phases in which they would get benefits as a result of realizing the need to overcome business challenges that have affected the lifestyle and society at large. Similarly, companies must also look for relevant measures that could be incorporated on their social media platforms along with significant features for bringing a positive change in consumer behavior. This would be considered as one of the most important factors in generating profits and achieving the survival goals of the company.

Also, SMEs must use authentic services when promoting their businesses. In this regard, it is required that companies must understand online business policies so that it would become easy for them to initiate strategies upon which consumers could rely. Thus, companies must undergo different audits to ensure that all important measures are incorporated in social media where the main motive is to attract the consumers for the overall growth of the company.

Author Contributions: Conceptualization, A.A.K.; methodology, A.A.K.; software, A.A.K. and M.Z.W.; investigation, A.A.K.; writing-original draft preparation, A.A.K.; writing-review and editing, M.N., S.E. and M.H.H.; supervision, M.Z.W.; funding acquisition, A.A.K.

Funding: This research received no external funding.

Conflicts of Interest: The authors declare no conflict of interest.

\section{Appendix A}

Table A1. Major social media platforms.

\begin{tabular}{|c|c|c|c|c|}
\hline Social Media & Description & & Platform Environment & \\
\hline Facebook & $\begin{array}{c}\text { American-based social media platform, which provides } \\
\text { social network services to users since 2004. Mark } \\
\text { Zuckerberg launched the website with a motivation to } \\
\text { foster social networking and providing an easy space to } \\
\text { organizations for promoting their business across } \\
\text { the globe. }\end{array}$ & 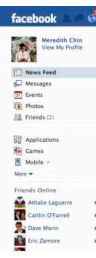 & 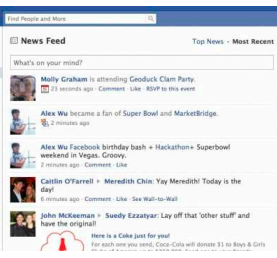 & 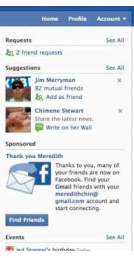 \\
\hline Instagram & $\begin{array}{l}\text { Facebook owned social platform which provides features } \\
\text { for sharing videos and images. Instagram was launched } \\
\text { in } 2010 \text { exclusively on iOS. }\end{array}$ & & 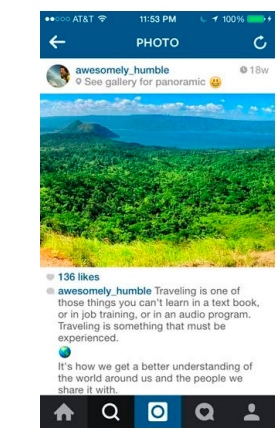 & \\
\hline
\end{tabular}


Table A1. Cont.

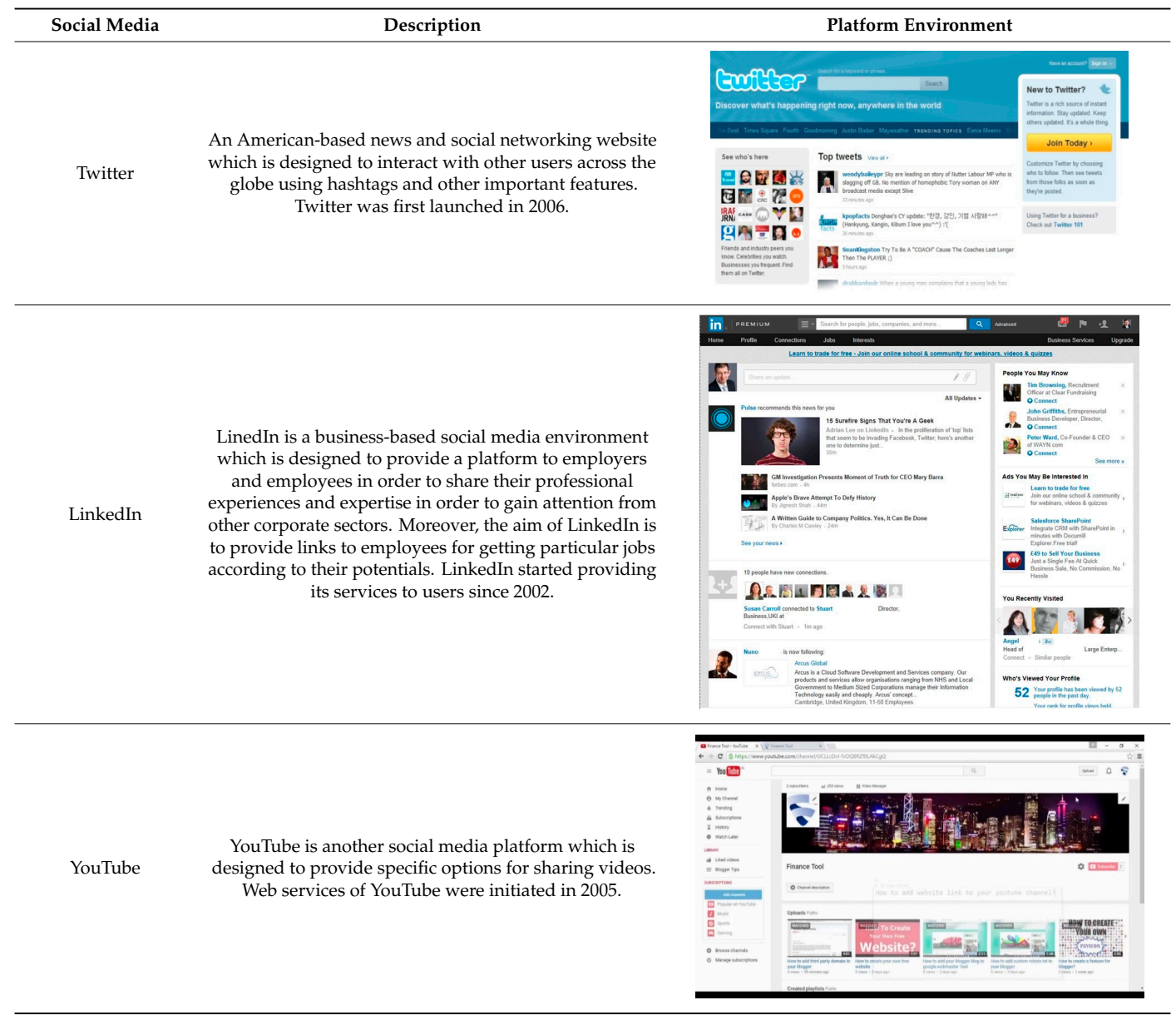

Questionnaire

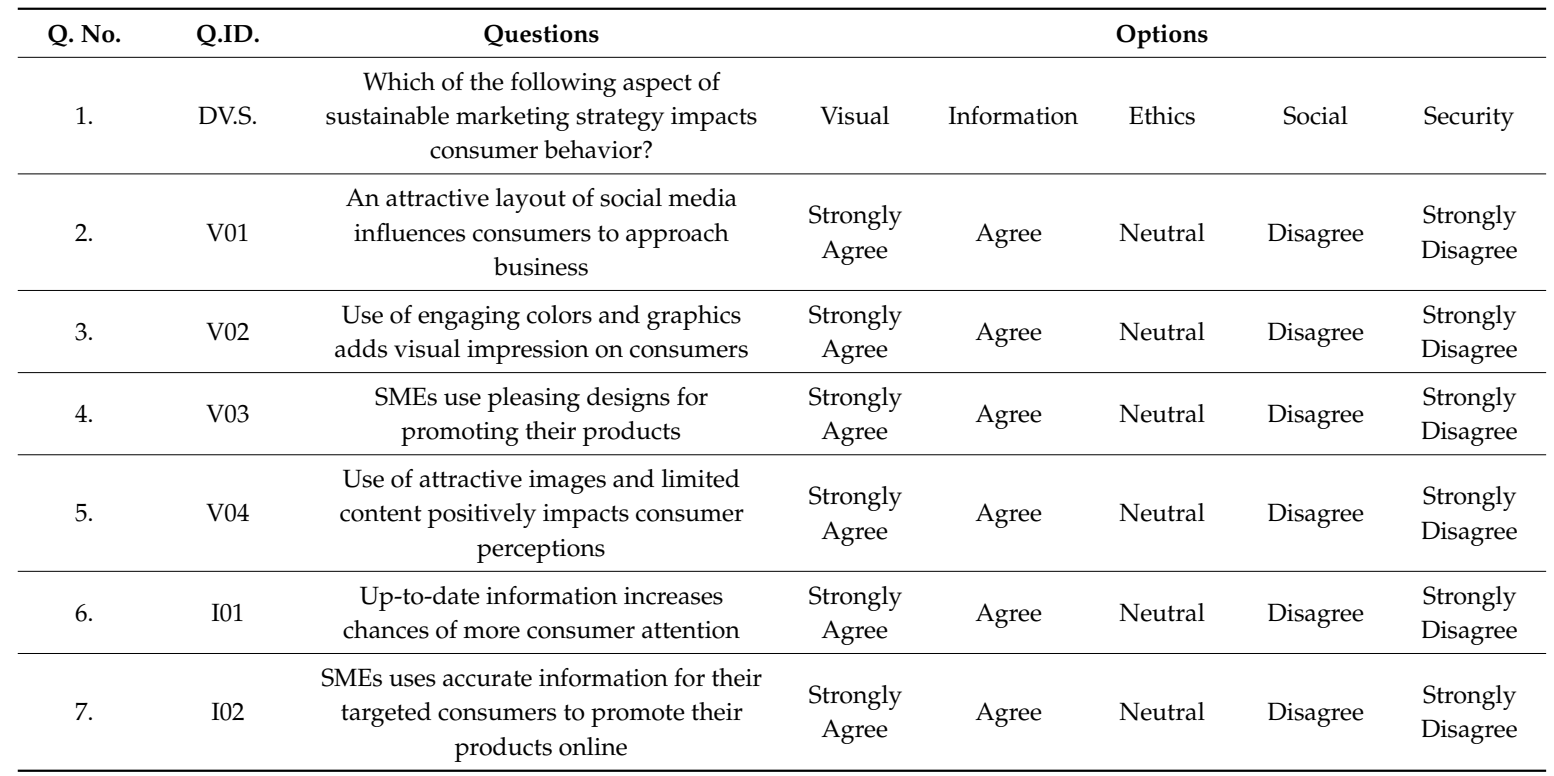




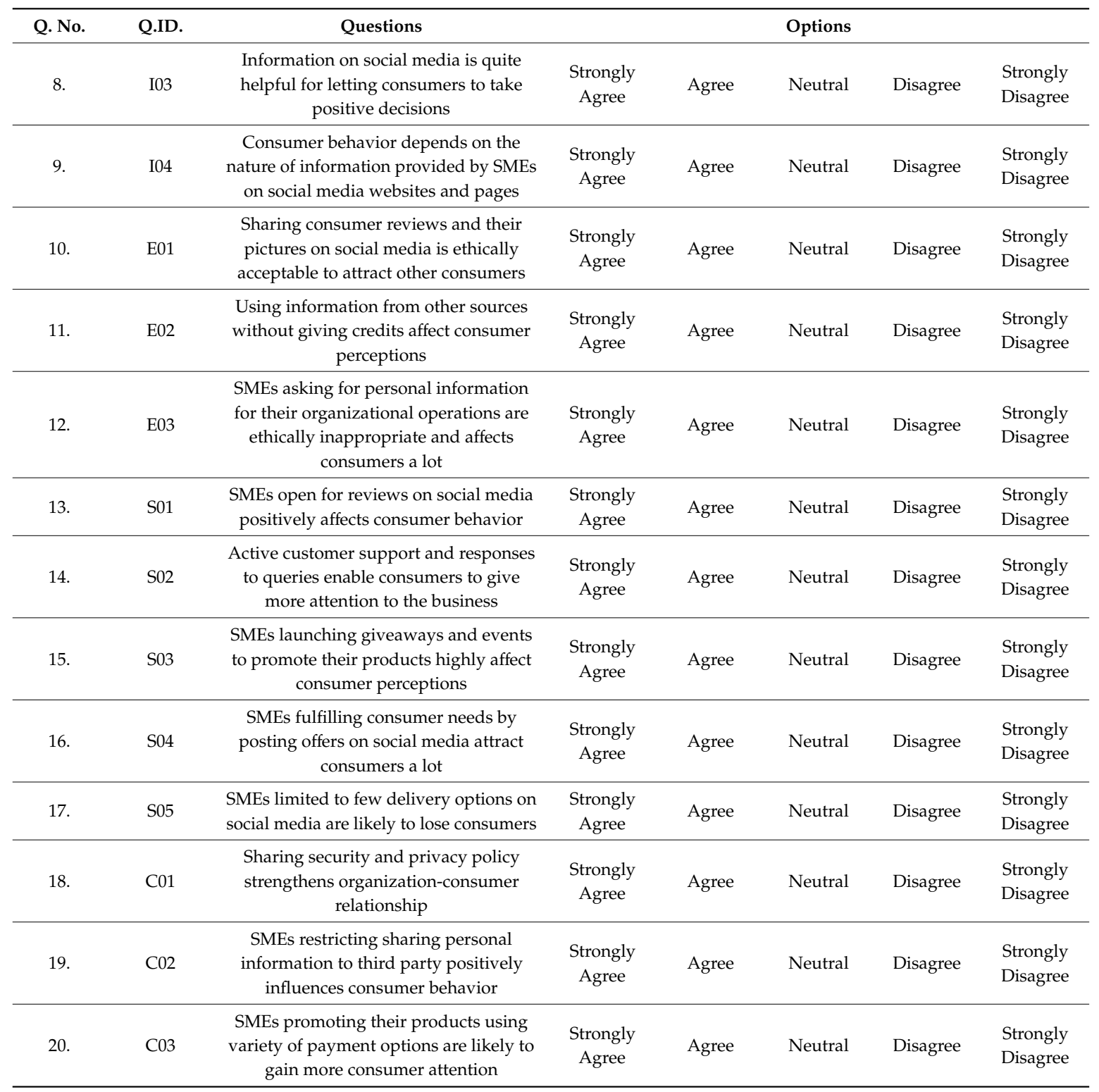

\section{References}

1. Minton, E.; Lee, C.; Orth, U.; Kim, C.; Kahle, L. Sustainable marketing and social media: A cross-country analysis of motives for sustainable behaviors. J. Advert. 2012, 4, 69-84. [CrossRef]

2. Jianu, I.; Ţurlea, C.; Guşatu, I. The Reporting and Sustainable Business Marketing. Sustainability 2016, 8, 23. [CrossRef]

3. Ingenbleek, P.T.M.; Meulenberg, M.T.G.; van Trijp, H.C.M. Buyer social responsibility: A general concept and its implications for marketing management. J. Mark. Manag. 2015, 31, 1428-1448. [CrossRef]

4. Ha, Y.; Lennon, S.J. Consumer responses to online atmosphere: The moderating role of atmospheric responsiveness. J. Glob. Fash. Mark. 2011, 2, 86-94. [CrossRef]

5. Pateli, A.; Mikalef, P. Configurations explaining Social Media's Impact on Innovation Performance. In Proceedings of the Pacific Asia Conference on Information Systems, Langkawi, Malaysia, 16-20 July 2017.

6. Guha, S.; Harrigan, P.; Soutar, G. Linking social media to customer relationship management (CRM): A qualitative study on SMEs. J. Small Bus. Entrep. 2018, 30, 193-214. [CrossRef]

7. Mangles, C. How Businesses Use Social Media: 2017 Report. Smart Insights, 2017. Available online: https://www.smartinsights.com/social-media-marketing/social-media-strategy/businesses-usesocial-media-2017-report/ (accessed on 8 May 2019). 
8. Schmidt, F.C.; Zanini, R.R.; Korzenowski, A.L.; Junior, R.S.; do Nascimento, K.B.X. Evaluation of sustainability practices in small and medium-sized manufacturing enterprises in Southern Brazil. Sustainbility 2018, 10, 2460. [CrossRef]

9. Fan, K.-K.; Feng, T.-T. Discussion on Sustainable Development Strategies of the Traditional Handicraft Industry Based on Su-Style Furniture in the Ming Dynasty. Sustainability 2019, 11, 2008. [CrossRef]

10. Srinivasan, R.; Bajaj, R.; Bhanot, S. Impact of Social Media Marketing Strategies used by Micro Small and Medium Enterprises (MSMEs) on Customer acquisition and retention. IOSR J. Bus. Manag. (IOSR-JBM) 2016, 18, 91-101.

11. Dutot, V.; Bergeron, F. From strategic orientation to social media orientation: Improving SMEs' performance on social media. J. Small Bus. Enterp. Dev. 2016, 23, 1165-1190. [CrossRef]

12. Ma, J.; Wang, J.; Szmedra, P. Sustainable Competitive Position of Mobile Communication Companies: Comprehensive Perspectives of Insiders and Outsiders. Sustainability 2019, 11, 1981. [CrossRef]

13. Hitchen, E.L.; Nylund, P.A.; Ferràs, X.; Mussons, S. Social media: Open innovation in SMEs finds new support. J. Bus. Strategy 2017, 38, 21-29. [CrossRef]

14. Maheswari, H.; Yudoko, G.; Adhiutama, A. Government and Intermediary Business Engagement for Controlling ElectronicWaste in Indonesia: A Sustainable Reverse Logistics Theory through Customer Value Chain Analysis. Sustainability 2019, 11, 732. [CrossRef]

15. Hajli, M.N. A study of the impact of social media on consumers. Int. J. Mark. Res. 2014, 56, 387-404. [CrossRef]

16. Siricharoen, W.V. Social Media, How does it Work for Business? Int. J. Innov. Manag. Technol. 2012, 3, 476. [CrossRef]

17. Yan, L.; Musika, C. The Social Media and SMEs Business Growth. How can SMEs Incorporate Social Media. 2018. Available online: http://www.diva-portal.org/smash/get/diva2:1210927/FULLTEXT01.pdf (accessed on 9 May 2019).

18. Darban, A.; Li, W. The Impact of Online Social Networks on Consumers' Purchasing Decision. Master's Thesis, 2012. Available online: http://www.diva-portal.org/smash/get/diva2:532049/FULLTEXT02 (accessed on 9 May 2019).

19. Lee, E. Impacts of Social Media on Consumer Behavior: Decision Making Process. Bachelor's Thesis, Turku University, Turku, Finland, 2013.

20. Mount, M. University of California Press. Mankind 2010, 13, 293.

21. Ainin, S.; Parveen, F.; Moghavvemi, S.; Jaafar, N.I.; Shuib, N.L.M. Factors influencing the use of social media by SMEs and its performance outcomes. Ind. Manag. Data Syst. 2015, 115, 570-588. [CrossRef]

22. Felipe, B.; Pereira, E.; Brito, Z. Determinants of Social Media Adoption by Large Companies. J. Technol. Manag. Innov. 2018, 13, 11-18.

23. McCay-Peet, L.; Anabel, Q.-H. A model of social media engagement: User profiles, gratifications, and experiences. In Why Engagement Matters; Springer: Cham, Switzerland, 2016; pp. 199-217.

24. Westin, A.L.; Kalmykova, Y.; Rosado, L. Method for quantitative evaluation of sustainability measures: A systems approach for policy prioritization. Sustainability 2019, 11, 734. [CrossRef]

25. Samuel Fosso, W.; Lemuria, C. Social Media Tools Adoption and Use by SMEs: An Empirical Study. In Social Media and Networking: Concepts, Methodologies, Tools, and Applications; Information Resources Management Association, Ed.; IGI Global: Hershey, PA, USA, 2016; pp. 791-806.

26. Wirtz, B.W.; Piehler, R.; Ullrich, S. Determinants of social media website attractiveness. J. Electron. Commer. Res. 2013, 14, 11.

27. Liu, H.; Chu, H.; Huang, Q.; Chen, X. Enhancing the flow experience of consumers in China through interpersonal interaction in social commerce. Comput. Hum. Behav. 2016, 58, 306-314. [CrossRef]

28. Martins, J.; Gonçalves, R.; Oliveira, T.; Cota, M.; Branco, F. Understanding the determinants of social network sites adoption at firm level: A mixed methodology approach. Electron. Commer. Res. Appl. 2016, 18, 10-26. [CrossRef]

29. Kaur, S.; Lal, A.K.; Bedi, S.S. Do Vendor Cues Influence Purchase Intention of Online Shoppers? An Empirical Study Using SOR Framework. J. Internet Commer. 2017, 16, 343-363.

30. Jamalzadeh, M.; Behravan, N.; Espahbodi, S.; Masoudi, R. An empirical analysis of online social network determinants towards business prosperity. Bus. Econ. J. 2012, 2012, BEJ57. 
31. Sutton, J. Why Social Media and Sustainability Should Go Hand in Hand. Available online: https://www. triplepundit.com/story/2016/why-social-media-and-sustainability-should-go-hand-hand/25341 (accessed on 4 April 2019).

32. Belz, F.M. Business Strategy and the Environment; Wiley Online Library: Hoboken, NJ, USA, 2006.

33. Marketing, S.; Conception, A.I. Sustainability Marketing: An Innovative Conception of Marketing. Mark. Rev. St Gallen 2010, 27, 8-15.

34. McDonagh, P.; Prothero, A. Sustainability marketing research: Past, present and future. J. Mark. Manag. 2014, 30, 1186-1219. [CrossRef]

35. Kang, M.Y.; Park, B. Sustainable Corporate Social Media Marketing Based on Message Structural Features: Firm Size Plays a Significant Role as a Moderator. Sustainability 2018, 10, 1167. [CrossRef]

36. Lazaris, C.; Vrechopoulos, A.; Doukidis, G.I. Physical web atmospherics: Utilising internet of things to conceptualise store atmosphere in omnichannel retailing. Int. J. Technol. Mark. 2017, 12, 389-416. [CrossRef]

37. Davis, L.; Wang, S.; Lindridge, A. Culture influences on emotional responses to on-line store atmospheric cues. J. Bus. Res. 2008, 61, 806-812. [CrossRef]

38. Floh, A.; Madlberger, M. The role of atmospheric cues in online impulse-buying behavior. Electron. Commer. Res. Appl. 2013, 12. [CrossRef]

39. Dailey, L. Navigational web atmospherics: Explaining the influence of restrictive navigation cues. J. Bus. Res. 2004, 57, 795-803. [CrossRef]

40. Da Silva, T.; Friberg, A. A Literature Review of the Field of Social Media in Retail. 2017. Available online: http://www.diva-portal.org/smash/get/diva2:1076196/FULLTEXT01.pdf (accessed on 9 May 2019).

41. Savelli, E.; Cioppi, M.; Tombari, F. Web atmospherics as drivers of shopping centres' customer loyalty. Int. J. Retail Distrib. Manag. 2017, 45, 1213-1240. [CrossRef]

42. Putri, K.D.; Balqiah, T.E. Do Web Atmospherics Affect Purchase Intention? The Role of Color and Product Display. J. Mang. Mark Rev. 2017, 2, 79-86.

43. Hoffman, D.L.; Novak, T.P. Marketing in Hypermedia Computer-Mediated Environments: Conceptual Foundations. J. Mark. 1996, 60, 50-68. [CrossRef]

44. Chen, Q.; Wells, W.D. Attitude toward the Site. J. Advert. Res. 1999, 39. [CrossRef]

45. Koo, W.; Park, H. Critical Atmospheric Cues in Designing Online Stores: The Case of Amazon. Int. J. Mark. Stud. 2017, 9, 37. [CrossRef]

46. Chen, Y.-S.; Lin, C.K.; Lin, C.Y.; Chuang, H.M. Electronic commerce marketing-based social networks in evaluating competitive advantages using SORM. Int. J. Soc. Humanist. Comput. 2017, 2, 261-277. [CrossRef]

47. Mukhopadhyay, K. Ethical Dimensions of Social Media Usage: A Case Study of Hokkolorob. Available online: http://www.caluniv.ac.in/global-mdia-journal/SR-Nov-2017/SR\%201.pdf (accessed on 9 May 2019).

48. Yosilia, E.; Longdong, E.; Pangemanan, S.S. Analyzing the Effect of Virtual Atmospheric Cues, Sales Promotions, and Situational Factors on Online Impulse Buying in Manado. J. EMBA 2015, 3, 119-129.

49. Tang, J.; Zhang, P. The impact of atmospheric cues on consumers' approach and avoidance behavioral intentions in social commerce websites. Comput. Hum. Behav. 2018. [CrossRef]

50. Dwivedi, Y.K.; Kapoor, K.K.; Chen, H. Social media marketing and advertising. Mark. Rev. 2015, 15, $289-309$. [CrossRef]

51. Lacoste, S. Sustainable value co-creation in business networks. Ind. Mark. Manag. 2016, 52, $151-162$. [CrossRef]

52. Rudell, F. The New Rules of Green Marketing: Strategies, Tools, and Inspiration for Sustainable Branding; Berrett-Koehler Publishers: Oakland, CA, USA, 2013.

53. Moltaji, N. Effects of Textual and Visual Information in Social Media on International Students' Choice of Study Destination: A Qualitative Study on How Forms of Information in Social Media Affect International Students' Decision-Making with Regards to the Choice of Study Destination. 2018. Available online: https://www.diva-portal.org/smash/get/diva2:1231111/FULLTEXT01.pdf (accessed on 9 May 2019).

(C) 2019 by the authors. Licensee MDPI, Basel, Switzerland. This article is an open access article distributed under the terms and conditions of the Creative Commons Attribution (CC BY) license (http://creativecommons.org/licenses/by/4.0/). 